Türkmen, G. P. \& Soybaş, D. (2019). The Effect Of Gamification Methodology On Students' Achievements and Attitudes Towards Mathematics. Bartın University Journal of Faculty of Education, 8(1), 258-.298

Bartın University Journal of Faculty of Education, 8(1), 258-298

Bartın Üniversitesi Eğitim Fakültesi Dergisi, 8(1), 258-298

buefad.bartin.edu.tr

\title{
The Effect Of Gamification Methodology On Students' Achievements and Attitudes Towards Mathematics
}

\author{
Gökçe Pelin TÜRKMEN*a, Doç. Dr. Danyal SOYBAŞ ${ }^{\mathrm{b}}$
}

\begin{tabular}{l} 
Article Info \\
\hline DOI: 10.14686/buefad.424575 \\
\hline Article History: \\
Received $\quad 17.05 .2018$ \\
Accepted 05.01 .2019 \\
Published $\quad 01.02 .2019$ \\
\hline Keywords: \\
Mathematics, \\
Gamification, \\
Educational Games \\
\hline Article Type: Research Article
\end{tabular}

\begin{abstract}
The aim of this study is to search the effect of gamified gamification methodology on 5th grade students' achievement and attitude in Mathematics classes. In accordance with this purpose, the subject of fractions has been prepared as game based and Educational Informatics Network (known as EBA in Turkey) games and applications have been used as teaching materials. There are a total of 50 students $(\mathrm{N}=50)$, namely, 28 students in experimental group and 22 students in control group. In this study, mixed method has been used by combining quantitative research and qualitative research method. For the quantitative part, pretest - posttest control group quasi-experimental design have been used. Quanitative data have been supported by qualitative data, obtained from in-class observations and unstructured interviews with students. The data gained from experimental group and control group have been analyzed in the SPSS program. As a result, it has been found out no statistically significant difference between the achievement and attitude scores of the students in the experimental and control groups. However, it has been observed that the achievement of the students in the experimental group increased more than that of the students in the control group.
\end{abstract}

\section{Oyunlaştırma Yöntemiyle Öğrenmenin Öğrencilerin Matematik Başarılarına ve Derse Yönelik Tutumlarına Etkisi}

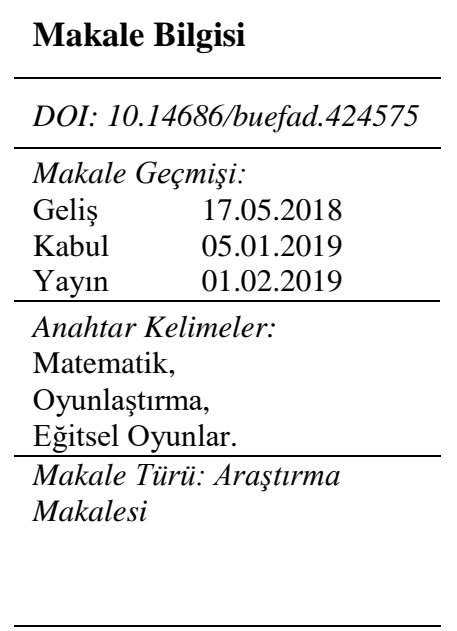

\begin{abstract}
$\ddot{O} z$
Araştırmanın amacı, oyun temelli öğrenmenin 5. sınıf öğrencilerinin Matematik dersindeki başarılarına ve tutumlarına etkisini araştırmaktır. Bu amaç doğrultusunda "Kesirler" ünitesi ders planı oyunlaştırılmış olarak hazırlanmış ve öğretim materyali olarak da Eğitim Bilişim Ağı oyunları kullanılmıştır. Araştırmanın deney grubunda 28 öğrenci, kontrol grubunda 22 öğrenci olmak üzere toplam 50 öğrenci bulunmaktadır. Nicel ve nitel araștırma yöntemlerin bir arada kullanıldığ 1 bu araștırmada bu iki yöntemin birleştirildiği karma yöntem kullanılmıştır. Nicel araştırma yöntemi olarak deneysel araştırma yöntemlerinden, ön test - son test kontrol gruplu yarı deneysel desen kullanılmıştır. Elde edilen nicel veriler, sınıf içi gözlemler ve ögrencilerle yapılan yapılandırılmamış görüşmeler sonucunda elde edilen nitel veriler ile desteklenmiştir. Yapılan uygulamalar SPSS programında analiz edilerek sonuçlar elde edilmiştir.Sonuç olarak deney ve kontrol gruplarında öğrenim gören öğrencilerin başarı ve tutum puanları arasında istatistiksel olarak anlamlı bir farklılık bulunmamıştır. Fakat deney grubu öğrencilerinin başarıları, kontrol grubundaki ögrencilere göre daha fazla artış göstermiştir.
\end{abstract}

\footnotetext{
*Corresponding Author: p.bozdogan@ hotmail.com

${ }^{a}$ The Title of the Author 1, p.bozdogan@ hotmail.com, https://orcid.org/0000-0001-5018-8329

bThe Title of the Author 2, danyal@erciyes.edu.tr, Doç. Dr., Erciyes University, Kayseri/Turkey, http://orcid.org/0000-00028140-9435
} 


\section{Introduction}

As science and technology are developing rapidly, it is quite difficult to transfer information using traditional methods, as it was in the past. Considering this situation, it is necessary to educate self-confident individuals who are independent, creative, questioning, aware of the problems they encounter and producing solutions by making changes in the curriculum programs. According to this, an educational environment should be prepared in which the students take center and students feel free. Parallel to the fact that all the countries in the world follow each other, the need to search for new horizons in education has arisen.

Information and communication technology (ICT) has a continuously changing structure. The innovations and changes that take place day after day in this area lead to the intensive use of this field in education. Taking this into account, it is inevitable for countries to incorporate technology into their education system. In line with these results, the investments made by countries in educational technology have increased and continue to increase. Thanks to the technology used in education, computers, tablets and smart boards have been introduced into educational environments and the number of such technologies is increasing day by day. In recent years, smart boards have provided teachers with various facilities for teaching. These boards are preferred because of saving time and canalizing to different learning styles by using text, audio, video etc.

When the motivation of the computer and the interest of the students are considered, educational digital games can be used to reach the goals that MONE (Ministry of Nationaol Education) sets for students. With the use of the internet on smart boards, a variety of possibilities have become available to the students. Visually presented materials enable students to learn more permanently and make the lessons become enjoyable and more productive. EBA ,recently offered by MONE to all teachers and students, is rich in terms of lecturing, practice and play, and has been presented to the teachers' use.

Gamification is the use of game components outside the game to raise the student's motivation, performance and lecture involvement to the highest level. Gamification is based on motivation and it aims to internalize the external motivation provided by game components. According to Karabacak (1996), the first step of providing learning is to awaken interest, attention and motivation. For this purpose, it is stated that it is necessary to benefit from teaching with games in teaching activities. Şahin (2015) emphasizes that it will be interesting to give learning goals together with game components in order to provide a quality learning environment for the students and to provide meaningful learning in students. Active learning can be realized with the help of positive components that can make the education quality such as competition, entertainment, excitement offered by the games.

The Turkish Language Institute's game description mentions that game is an intelligence and talent developer tool, has certain rules, helps people get a good time. Playing games is the most essential requirement as the basic needs of children. Children, young people, old people play games to have fun from birth to death. From the time the babies are born, everything in their little worlds is based on games. Children are prepared for their future characters, postures and behaviors with the help of their gaming personalities. In games played with more than one person, communication with other people participating in the game is the beginning of social life. Games, which are fun events for people, have a very important place in children's mental development and learning. According to Şahin (1998), problem-solving skills of children who are playing games are improving,too. As a result, it has become inevitable for the games to take part in the curriculum.

Nowadays, the understanding of education is more like student-centered that the student come to a situation where he / she asks questions and is active, where the teacher directs them only in accordance with their needs, the student learn the truth on their own rather than the teacher-centered education that the teacher transfers all the necessary information to the student, the memorizing and the students are physically inactive. In traditional educational environments, there is a lot of memorization, so it is not enough to educate the individuals who are raised to meet the needs of today's society. Today, when the games which allow children to have fun are used in an educational environment by putting aside the traditional teaching methods that are lacking in meeting the needs of the society, learning environment becomes more enjoyable and also a way to move forward with more robust steps in reaching the goals and achievements set by the Ministry of National Education is chosen. In the study conducted by Şahin (2015) it has been seen that educational studies with educational games are at least as useful as traditional education methods.

In a study carried out by Tüzün (2006), it is stated that the use of these games during which students enjoy much and are eager to take part in is an issue that cannot be ignored and this makes the educational environments 
more enjoyable. When games are thought to be based on volunteerism and entertain students, digital games to be used in the classroom environment can make the goals and achievements more achievable. By taking the general expression of "they can not learn if they can not have fun" into consideration, learning is faster and longlasting in the educational environments that are acquired through games. In addition, supplementary games to be played in the classroom can be alternative the teaching and have had enriching effect on learning.

Games can be the cornerstone of an educational environment for students when they are fully prepared for acquisition. Educational games also contribute greatly to the development of problem solving skills, which are the most desirable features for mathematics in students. With educational games, students can get rid of shallow thinking and discuss world problems, and students can have an idea about life. Boring and hard-to-learn subjects may become enjoyable and easy to understand through educational games. While educational games are being prepared, if the new information are presented with the old information, the old information will be assigned to the new information. Thanks to educational games, old information can be reproduced without boredom. Passive, shy, hesitant students are motivated to attend classes. Learning in this way can be achieved for almost all students in different proficiency levels. Thanks to educational games, students are motivated in the lesson by increasing their desire to learn. This increases the sense of competence in the students and the subsequent success enhances their motivation for the lesson. The game is an indisputable issue in education and teaching environment because it provides an opportunity for practice not only in lessons but also after school.

Game-based learning developed based on learning of the students by playing games is a teaching environment which is prepared for the students to find the solutions they have found themselves or the solutions they have discovered while playing game by placing game problems in the game. As in the constructivist approach, in the game-based learning environments, the student himself / herself reaches the target behavior with his / her existing knowledge, compares the old knowledge and the new knowledge reached, adds new knowledge on existing knowledge to produce new and different solutions. In this way, the student constructs his / her knowledge. As it is understood from this, in the game-based learning environments, students learn away from the memorization and observes the new knowledge based on the research and inquiry. One of the studies supporting this idea is Aksoy (2014). In this study, it has been seen that although students have easy access to the information, they have tried to reach the knowledge through their own hands and to find solutions with different solutions. Based on this information, it can be said that game-based learning can have positive effects on students' learning experiences. When the literature review is made, similar results are seen in some of the studies (Sönmez \& Dinç, 2011, Korkusuz, 2012, Aksoy, 2014).

Old games played in the neighbourhood have been moved to digital media with the developments in science and technology. Games are now being played extensively with technological devices such as tablets, computers, mobile phones and game consoles. It has been observed that students now spend their time with digital games rather than street games, and there is an increasing tendency for this. When we examine the study of Güneş (2010) on this subject, it is seen that digital products are used by students to play games and that students spend an average of three hours a week to play these games. Given the increasing interest in computer games and the increasing allocated time to them every day, we can use computer games to reach the specific and general goals set by MONE (Akpınar, 1999). Çetin (2013).It has been indicated that the rich stimuli and various problem scenarios presented by computer games will contribute to the students' cognitive development by providing entertaining mental activities. Thus, the disadvantages of students who spend hours playing games and are extremely willing to play these games can be turned into advantages thanks to educational digital games.

Educational Informatics Network (EBA), which has been created to help teachers and students in digital environment, is used as an online social education platform (Education Informatics Network, 2016) which is offered free of charge to the use of teachers and students by the General Directorate of Innovation and Educational Technologies. The EBA, which includes many educational services, is now being used extensively by primary and secondary school students and teachers. EBA was launched in 2012. It has been renewed by changing needs and has become the world's largest content serving system (Hürriyet Newspaper, 2016). EBA system was used by 10 million primary and secondary school students in 2015-2016 academic year (Milliyet Newspaper, 2016). Today the number is increasing.

EBA is the service of MoNE which aims to make it easy for students and teachers to use the newly established internet infrastructure in all schools where there are smart boards. EBA provides teachers with a lot of convenience in lecture and also providing students with many opportunities in terms of concretizing subjects, lecturing, practice, 
play and testing. The work of a teacher who teaches lessons with the EBA system has become easier and more enjoyable. With EBA games that are encouraged to be used in schools, students are now learning while having fun. Excited and competitive games played outside the school by students have been moved to the school environment while at the same time by playing these games without additional effort, students has comprehended the subject. At the same time,thanks to EBA, teachers can share information ,educational materials, games and lectures they use with each other in an easy way.

When the recent studies in this field are examined, the successes of classroom environments based on gamebased learning and traditional methods have been compared in the studies of Kibar (2006), Kablan (2010), Sönmez and Dinç (2011), Korkusuz (2012), Aksoy (2014). When these studies have been examined, it has been seen that student achievement in the game-based classroom environment is higher than in the traditional classroom environment. On the other hand, there are not significant difference between performance of the classroom environment teaching in which the game-based teaching method is used and the achievement of the classroom environment in which the traditional teaching method is used according to the studies of Obet (2005), Güneş (2010), Kula and Erdem (2006). However, they pointed out that using games in lessons, which are highly enjoyed by students in the game-based teaching environment, will provide a better quality educational environment for the students by increasing the diversity of the teaching environment. Another point that draws attention in researches is that classroom environments have increased the motivation of the students to take part in games.

The study is limited to 50 students in 5th grade in two state schools in Çiftlik in Niğde. The research is limited to the achievements of the 5th grade "Fractions" unit of mathematics during the implementation. The research findings are limited to questions of mathematics achievement test and mathematics attitude test applied to experiment and control group.

\section{Aim of The Study}

The aim of this study is to examine the effect of the fifth grade math class "Fractions" on the academic achievement and attitudes of game-based learning environments using games and applications in newly created Educational Informatics Network as opposed to traditional teaching methods.

\section{İmportance of The Research}

In today's science and technology era, change is inevitable in the educational system as it is in every part of society. Given this situation, a changeover has begun from teacher-centered education to student-centered education and from traditional education approach to constructivist education approach. Through the constructivist education approach, the student finds the truth on their own and has the opportunity to internalize the knowledge with different experiences. The use of technology in education largely compensates the inadequacy of teaching methods and presents new possibilities for learning. Along with constantly developing science and technology, the number of alternative ways in teaching environments has increased and as a result changes in education programs have become inevitable. For this reason, the curriculum that was being applied at the end of the 20052006 academic year by MONE has been renewed and the constructivist approach has begun to be applied throughout the country. As a result of the changes in education, mathematics lessons have begun to become more understandable as a result of constructivist approaches rather than being a lesson to memorize.

Today, the use of computer games to learn the interests and desires of the students is a subject of many researches and it is revealed in research results that the games have an important place in the development of children. Whelan (2005) notes that the number of educators and researchers supporting the idea that game-based learning has a great influence on educational environments is increasing day by day. Accordingly, Gee (2003), who thinks that games will improve education environments, has stated that in the imaginary world of welldesigned video and computer games, people are able to create themselves in a different way,and this will lead to not only having fun but also learning. Kirriemuir and McFarlane (2004) emphasize that thanks to games, people acquire skills such as planning, communication, etc. Similar to other researchers, Shaffer, Spuire, Halverson and Gee (2005) indicate that video games create social, cultural and intellectual world in humans, which in turn helps people foresee by using critical thinking, technology and social communication.

Mathematics is a system that exists in people's minds and it examines the abstract beings and their relations with each other. Mathematics is a discipline that focuses on characteristics of abstraction such as numbers, geometric shapes, spaces etc. and the relationship between them and their interrelatedness by using deductive path. It is a science that facilitates the lives of people through connections and explication. 
Mathematics is a goal to teach the habits of systematic and rational thinking, in order to uncover and direct the skills that exist in people. For this reason, the most important goal in all renewal studies related to education is to create an education system that will facilitate the understanding of mathematics by the students. Although mathematics has such an important place in human life, it is not liked much by students, it is found boring by students and it is thought to be an abstract lesson. Many students in our country are approaching mathematics with prejudice, considering that mathematics is a difficult subject to succeed. The feeling that students can not succeed causes them to be alienated from the subject and lack the foreknowledge. Recent studies in education aim to destroy the prejudice of the course (Yenilmez \& Dereli, 2009). The fear of mathematics is a prejudice which starts in primary school and is very difficult to break down in following years. It is aimed to make mathematics lessons more concrete and fun for students with games, real life cases and materials. Freud sees the game as a means to provide a suitable environment for children to accomplish what they want and overcome concerns. Since students are able to observe concrete mathematics lessons, start to notice the place of mathematics in their life and are getting active due to the understanding of the lesson, they start to love mathematics and therefore,their mathematical success can increase.

The game is a system in which the player performs the tasks he/she is asked for within the framework of a series of rules. Concepts, rules and problems in game-based learning environments are presented to students in the game scenario. While solutions are being produced during the game, the subjects that are dominant in the competition are fully consolidated and on the other hand the students are enabled to have fun.

\section{Research Problem and Sub Problems}

The main problem of this research is as follows: "What is the effect of game based learning on students' attitudes towards mathematics lesson and to their successes ?" And the sub-problems of the research are as follows:

1. Is there a meaningful difference between the pre-test and post-test achievement scores of the experimental group and the control group students?

2. Is there a meaningful difference between the pre-test and post-test attitude scores of the experimental group and the control group students?

3. Is there a meaningful difference between the pre-test and post-test achievement scores of the experimental group and the control group students according to gender?

4. Is there a significant difference between the pretest and posttest attitude scores of the students in the experimental group and the control group according to gender?

5. What are the opinions of the students about the game-based learning?

\section{Method}

\section{Research Design}

With this study it is aimed to investigate the effect of the gamification applied to 5th grade students in middle school on achievement and attitudes towards mathematics lesson. For this purpose, an embedded pattern has been used in this study from mixed patterns in which quantitative and qualitative research methods are used together. The embedded pattern is a method in which the findings obtained using quantitative research designs are supported by qualitative research(Büyüköztürk vd., 2008). The reason for preference of this design is that these quantitative data collected are more comprehensive when supported by qualitative data.

As a quantitative research method, semi-experimental design with pre-test and post-test control group, one of the experimental research models, has been used. This model has been preferred since there is no chance to determine the classes that gamification will be implemented before implementation and determine them objectively. In this pattern, both of the specified groups are tried to be matched according to certain variables. Matched groups are chosen objectively for the implementation groups. However, this matching does not guarantee that the groups to be studied are on an equal level. This is a serious shortcoming. But it is an alternative pattern to be used when there is no chance to make a choice. The purpose of using the semi-experimental design method is to test the difference between the change from one group to the other. At the beginning and end of the implementation, mathematics academic achievement test have been applied to the students who were in both 
experimental group and control group as pre-test and post-test. The mathematics course attitude scale prepared by Duatepe and Çilesiz (1999) has been applied as pre-test and post-test. As a result, changes in the academic achievements of 50 students and their attitudes towards mathematics have been examined.

\section{Sample and Study Group}

In spring semester of 2016-2017 academic year, A study group consisting of 5th grade students of two state schools located in Çiftlik in Niğde has been chosen. There are a total of 50 students in this study, 28 of them are the experimental group in the game-based learning environments and 22 of them are the control group in the traditional teaching environment. Appropriate sampling method has been used in the research. One of the 5th grades in the different schools has been the experimental group and the other has been the control group.

\section{Data Collection Tools}

The research has been carried out in the spring of 2016-2017 academic year with fifth grade students in Çiftlik in Niğde. 28 students are in the experimental group and 22 students are in the control group. The study has continued for 14 weeks, with 2 lessons per week. The research period is limited to 28 course hours. That the duration of the research is 28 lesson is due to the fact that games in Educational Information Network are designed according to mathematics teaching with digital educational games. While educational digital games and applications, which are used for mathematics lessons are very few in the past, this number has increased considerably thanks to EBA.

The theoretical part of the study has been obtained by searching the literature about the problem statement. Various means of measurement have been used to obtain the quantitative data of the study. Measurement instruments used in research are;

Mathematics success test: The multiple-choice academic achievement test, consisting of 20 questions, has been used by referring to opinions of education specialists to determine whether the experimental process applied to the students have a significant effect on the academic achievement of the students in the "Fractions". The reasons why multiple-choice tests are used in this research are better sampling of the multiple-choice tests, objectivity of scoring, better expression of the problems to be solved and reduction of error possibility in the measurement (Öncü, 2003).

The academic achievement test has been prepared taking into account the aims and student achievements of the "Fractions" unit in the 5th grade mathematics curriculum of the secondary school. Learning outcomes;

- Students will be able to position the unit fractions in the numerical axis.

- Students will be able to realize the integer fraction is a simple fraction sum with a natural number, and they will be able to convert a integer fraction to a compound fraction and a compund fraction to a integer fraction.

- Students will be able to line up the fractions which have the equal denominator and which one fraction is the fold the other one.

- Students will be able to calculate the requested fraction of a simple fraction and a fraction of a simple fraction using the unit fractions.

- Students will be able to understand that simplification and expansion do not change the value of the sequence and form fractions that are equivalent to any fraction.

- Students will be able to make addition and subtraction on two fractions which have equal denominator or the fractions that are the fold of one another.

- Students will be able to realize that decimal notations are a different expression of fractions and they write and read the decimal notation of fractions that can be expanded or simplified to be 10,100 , and 1000 .

- Students will be able to understand the function of the comma in decimal notation, the relation of numbers which comes before and after comma with their digit values and specify the digit names in decimal notation.

- Students will be able to position the numbers the decimal notation of which is given, in the numerical axis.

- Students will be able to add up and substract of the numbers given in decimal notation.

- Students will be able to position the fractions, the denominator of which is 100 , with percentage symbol $(\%)$. 
- Students will be able to corelate a percentage statement with a decimal notation and a fraction which symbolise the same magnitude; convert these notations into each other.

- Students will be able to compare the multiplicity in decimal and percentage notation in fractions.

In accordance with the learning outcomes, the questions in the sources including the learning outcomes of the 5th grade "Fractions" unit of the middle school have been examined and the research test has been prepared.

Table 1. Achievement Test Substance Analysis

\begin{tabular}{lll}
\hline & Substance Difficulty $(\mathrm{P})$ & Substance Discrimination (R) \\
\hline Question 1 & 0,86 & 0,35 \\
Question 2 & 0,40 & 0,35 \\
Question 3 & 0,60 & 0,42 \\
Question 4 & 0,40 & 0,42 \\
Question 5 & 0,84 & 0,64 \\
Question 6 & 0,42 & 0,35 \\
Question 7 & 0,76 & 0,35 \\
Question 8 & 0,56 & 0,64 \\
Question 9 & 0,40 & 0,42 \\
Question 10 & 0,58 & 0,35 \\
Question 11 & 0,40 & 0,57 \\
Question 12 & 0,40 & 0,42 \\
Question 13 & 0,42 & 0,35 \\
Question 14 & 0,42 & 0,42 \\
Question 15 & 0,40 & 0,35 \\
Question 16 & 0,42 & 0,42 \\
Question 17 & 0,56 & 0,42 \\
Question 18 & 0,40 & 0,42 \\
Question 19 & 0,40 & 0,42 \\
Question 20 & 0,72 & 0,35 \\
Mean & 0,51 & 0,42 \\
\hline
\end{tabular}

The reliability of the test with the findings obtained has been found to be 0.60 as the internal consistency of the test calculated with KR-20; average substance difficulty value to be 0,51 ; the average discriminant value of the test has been found to be 0.42 . The correct answers in the achievement test have been evaluated as 1 point, the wrong and blank answers as 0 points. The students have been assessed with a score of at most 20 and at least 0 from the academic achievement test.

Mathematics course attitude scale. The "Mathematics Attitude Scale" developed by Duatepe and Çilesiz (1999) has been used to measure students' attitudes towards mathematics lessons. This attitude scale has been applied to the students twice as pre-test and post-test. Attitude scale reliability test has been conducted in SPSS and when pre-test results are evaluated, Cronbach's Alpha score has been found as 0.887 . This result indicates that the attitude scale is reliable.

Unstructured interview. An unstructured interview has been conducted to get students' views on the implementation. The questions are not prepared previously and the interview results have been noted.

\section{Implementation Process}

In the experimental group, game-based gamification method has been applied and in this context some games are provided with their comments. 


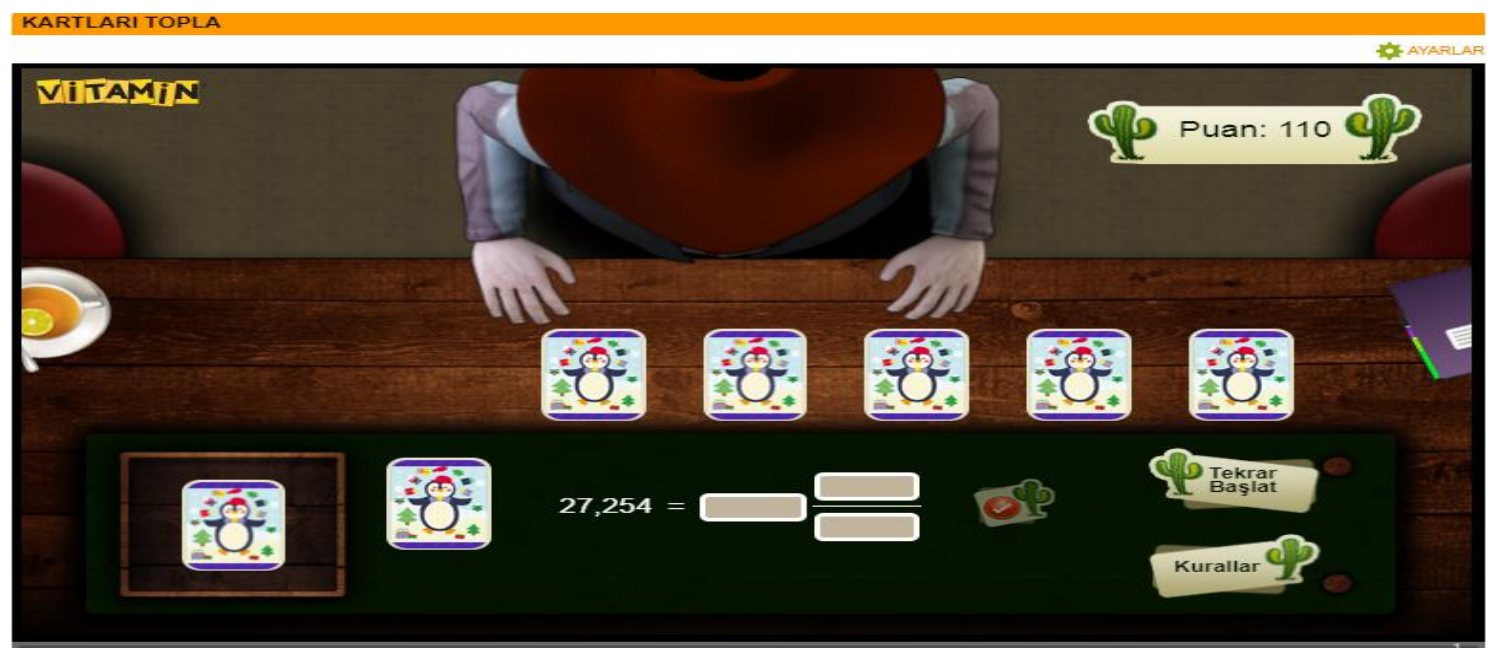

Figure 1. Game Sample

It is aimed to convert the decimal representation to a fractional representation and a fractional representation to a decimal representation in the game. Students convert the fractional or decimal notations from the selected card to the desired format and if the answer is correct, s/he will get points from the process and lose if it is wrong. Again in this score-based game, students want to get the highest score to enter a competitive environment. Although the aim is to pass on friends in the game, the subject has been indirectly comprehended.

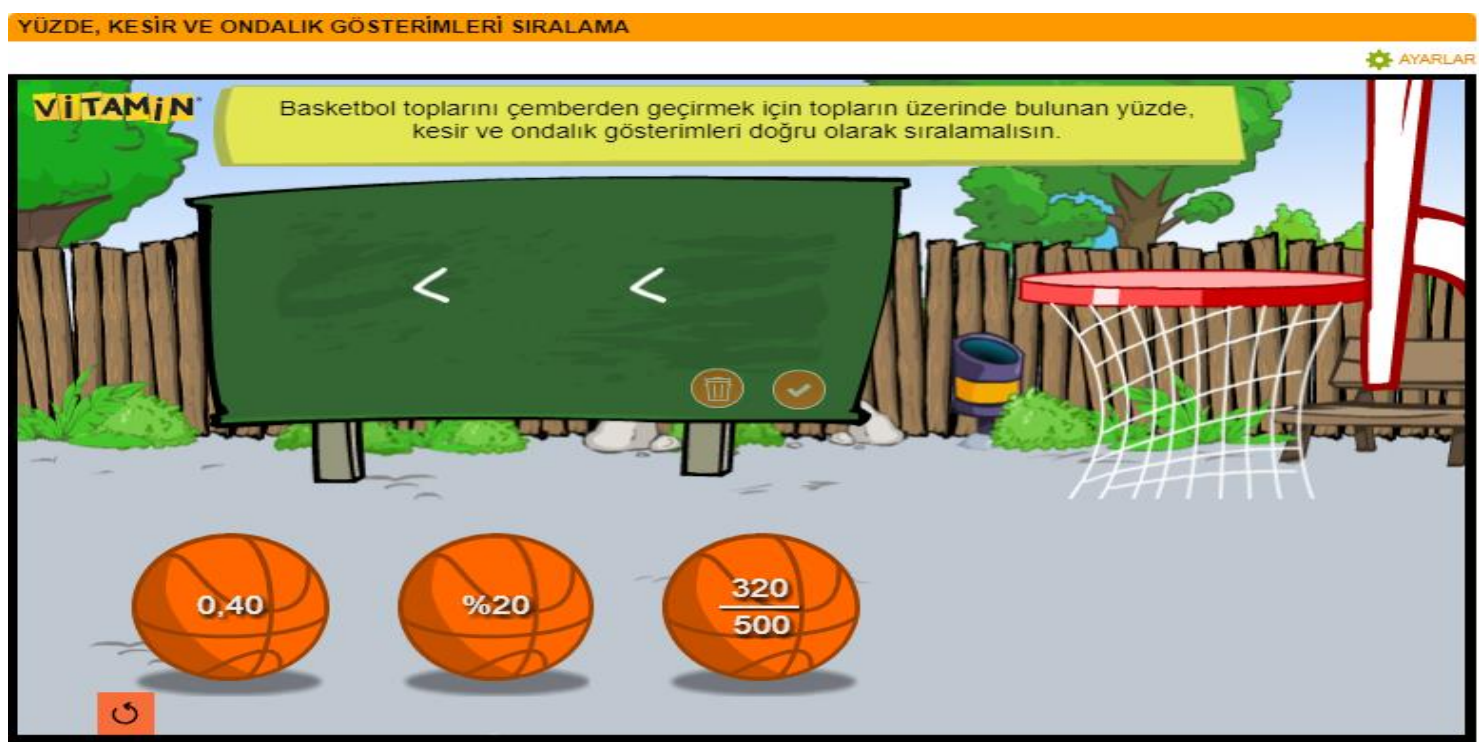

Figure2. Game Sapmle

This game has been played in accordance with the learning outcome which is comparing the multiples iindicated by fraction, decimal and percentage notation. In order to be able to throw the balls into the basket, the student must firstly point all the statements in a fractional notation, decimal notation or percentage notation. The student who shows all the statements with the same notation gets the chance to shoot the balls in the basket. Students also have started playing this game by simplifying and expanding the fractions. When the students are told to put the fractions in order in direct instruction technique, students who are not very willing even have played the game with great enthusiasm. That a student who lines up the fractions in a wrong way misses the chance to throw the ball has created an excitement among students. Even if certain students do it right,the fact that all students try to attend the course and start doing it right motivate the other students and at the same time these lead the students to obtain the learning outcomes completely.

\section{Data Analysis}


Quantitative data analysis. Experimental data obtained in the study were analyzed using SPSS (The Statistical Packet for the Social Sciences) package software.

Qualitative data analysis. Qualitative research methods are one of the ways in which people are aware of their qualities and produce the information they have developed to research and shape the depths of the community to which they contribute. Qualitative research methods play an important role in bringing out the unfamiliar situations underlying the events. It is important to reveal people's point of view of life. It is very important for us to show the daily life with all its clarity.

In this study, an embedded pattern has been used to support empirical and relational research from quantitative research designs with qualitative studies. Observation notes and interviews are often used in embedded pattern studies. The purpose of this is to support the qualitative and quantitative data obtained each other, and as a result, to reach more comprehensive and reliable information. The data obtained have been collected and the investigated situation has been enriched and in-depth information has been obtained about the situation. While the data of qualitative researches are collected, an approach which is called "triangulation" and in which multiple data acquisition methods and techniques are used is adopted.

In this study, open-ended questions and unstructured interview have been used as means for collecting data. Open-ended questions have been asked to students when something unusual happened during practice. After 14 weeks of practice, unstructured interviews have been conducted with the volunteer students in the experimental group. Interviews conducted have been noted down.

Notes taken from unstructured interviews during implementation are objectively combined and arranged to analyze.

\section{Findings}

\section{Findings and Explications on the First Problem of the Research}

The first problem of the study has been determined as "Is there a meaningful difference between the pre-test and post-test achievement scores of the experimental group and the control group students? and data have been analyzed by t-test. The mathematical achievement test has been applied as a pre-test to the students in the experimental group and the control group to determine whether the experiment and control groups corresponded to each other's success before the research. When the scores of students in the experimental and control groups have been compared in terms of mathematics achievement test, they have been analyzed using independent t-test for unrelated samples to determine whether there is a significant relationship between the scores and the findings are shown in Table 2.

Table 2. Unrelated Sample t-test Results of Pre-test Scores of Students in Experimental and Control Groups

\begin{tabular}{lllllll}
\hline Groups & $\mathrm{n}$ & $\mathrm{B}$ & $\mathrm{s}$ & $\mathrm{sd}$ & $\mathrm{t}$ & $\mathrm{p}$ \\
\hline Experimental & 28 & 10,1429 & 3,09975 & 48 &,- 483 &, 631 \\
Control & 22 & 10,5909 & 3,44562 & & & \\
\hline
\end{tabular}

When Table 2 is examined, it has been concluded that the pre-test average applied to the students in the experimental group is $\mathrm{B}=10,14$ and the pre-test average applied to the students in the control group is $\mathrm{B}=10,59$. When the table is examined, it has been seen that there is no significant difference between the groups in terms of the success average of mathematics lessons before the implementation although the average of the pre-test success scores of the students in the control group was higher than the pre-test success scores of the students in the experimental group. $(\mathrm{t}=-0,483, \mathrm{p}>0.05)$.

In order to determine the effect of the two different teaching methods applied in the study on the students' mathematical success, t-test (Paired Samples t-test) has been used for the related samples to determine whether there is a significant difference between the students in the experimental group and the students in the control 
group between pre-test and post-test achievement scores. The relation between the pre-test achievement score and the post-test achievement score applied to the students in the control group before the experimental procedure is shown in Table 3.

Table 3. Pre-test and post-test success scores of the students in the control group related sample t-test analysis results.

\begin{tabular}{lllllll}
\hline Tests & $\mathrm{n}$ & $\mathrm{B}$ & $\mathrm{s}$ & $\mathrm{sd}$ & $\mathrm{t}$ & $\mathrm{p}$ \\
\hline Pre-test & 22 & 10,5909 & 3,44562 & 21 & 14,417 &, 000 \\
Post-test & 22 & 13,2727 & 3,97830 & & & \\
\hline
\end{tabular}

When Table 3 is examined, it has been seen that the pre-test average success score of the students in the control group is B = 10,59 and the average of post-test success scores obtained at he end of 14 weeks is $B=13,27$. A statistically significant difference has been found between pre-test and post-test achievement scores of the students $(\mathrm{t}=14.417, \mathrm{p}<0.05)$. According to these results, it can be said that mathematics teaching with traditional teaching methods has a positive effect on the learners' learning.

For the students in the experiment group, t-test (Paired Samples t-test) has been used for the related samples to determine whether there is a relation between the pre-test success scores and the post-test success scores. The results are shown in Table 4.

Table 4. The Related Sample t-test Analysis Results of pre-test and post-test success scores of the students in the experimental group

\begin{tabular}{lllllll}
\hline Tests & $\mathrm{n}$ & $\mathrm{B}$ & $\mathrm{s}$ & $\mathrm{sd}$ & $\mathrm{t}$ & $\mathrm{p}$ \\
\hline Pre-test & 28 & 10,1429 & 3,09975 & 27 & $-6,850$ &, 000 \\
& & & & & \\
Post-test & 28 & 13,3929 & 4,47494 & & & \\
\hline
\end{tabular}

When Table 4 is examined, it has been observed that the pre-test average success score of the students in the experiental group is $\mathrm{B}=10,14$, and the average of post-test success scores obtained at the end of 14 weeks is $\mathrm{B}=$ 13,39. A statistically significant relation has been found between the pre-test success scores and the post-test success scores of the students in the experimental group in the post-test direction $(t=-6.850, p<0.05)$. This finding suggests that the game-based teaching method plays a positive role in the learning of the students.

Independent $\mathrm{t}$-test has been used to determine whether there is a meaningful difference between the post-test success scores of the students in the experimental group and the control group in which different methods were applied at the end of 14 weeks of implementation.Analysis results are shown in Table 5.

Table 5. Unrelated Sample t-test Analysis Results of Post-test Success Scores of Students in the Experimental Group and in the Control Group

\begin{tabular}{lllllll}
\hline Groups & $\mathrm{n}$ & $\mathrm{B}$ & $\mathrm{s}$ & $\mathrm{sd}$ & $\mathrm{t}$ & \\
\end{tabular}




\begin{tabular}{lcccccc}
\hline Experimental & 28 & 13,3929 & 4,47494 & 48 &, 099 &, 922 \\
Control & 22 & 13,2727 & 3,97830 & & & \\
\hline
\end{tabular}

When Table 5 is examined, it has been concluded that the post-test average success score of the students who are in the experiment group in which the game-based learning environments are used is B = 13,39, and the posttest success average of the students who are in the control group in which the traditional teaching method is used is $B=13,27$. When the findings are examined, it has been found that there is no statistically significant difference between the post-test success scores of the students in the experimental group and the post-test success scores of the students in the control group $(\mathrm{t}=0,116, \mathrm{p}>0.05)$.

\section{Findings and Explications on the Second Problem of the Research}

The second problem of the study is "Is there a meaningful difference between the pre-test and post-test attitude scores of the experimental group and the control group students?" Data have been analyzed by t-test. The mathematics attitude test has been applied as a pre-test to the students in the experimental and control groups to determine whether the students in the experimental group and the students in the control group are on the equal footing with each other according to their attitude scores. Independent t-test has been used to determine whether there is a significant relation between the scores, obtained from the attitude test, of the students in the experimental and control groups. The results are shown in Table 6.

Table 6. Unrelated Sample t-test Analysis Results of Pre-test Attitude Scores of Students in the Experimental Group and in the Control Group

\begin{tabular}{lllllll}
\hline Group & $\mathrm{n}$ & $\mathrm{B}$ & $\mathrm{s}$ & $\mathrm{sd}$ & $\mathrm{t}$ & $\mathrm{p}$ \\
\hline Experimental & 28 & 2,9126 &, 21041 & 48 &, 074 &, 942 \\
Control & 22 & 2,9079 &, 24019 & & & \\
\hline
\end{tabular}

When Table 6 is examined, it has been observed that the average of the pre-test attitude scores of the students in the experimental group is $\mathrm{B}=2.91$, and the average of pre-test attitude scores of the students in the control group is $\mathrm{B}=2.90$. When the results are examined, it has been found that there is no statistically significant difference between the pre-test attitude scores of the students in the experimental group and the pre-test attitude scores of the students in the control group $(\mathrm{t}=0,074, \mathrm{p}>0.05)$.

The t-test (Paried Samples t-test) has been used for the related samples to determine whether there is a significant relation between the pre-test attitude scores of the students who completed the process with the constructivist method in the control group and the post-test attitude scores obtained at the end of 14 weeks. Pretest attitude and post-test attitude scores of the students in the control group are shown in Table 7.

Table 7. Related Sample t-test Analysis Results of Pre-test and Post-test Attitude Scores of the Students in the Control Group

\begin{tabular}{lllllll}
\hline Test & $\mathrm{n}$ & $\mathrm{B}$ & $\mathrm{s}$ & $\mathrm{sd}$ & $\mathrm{p}$ \\
\hline
\end{tabular}




\begin{tabular}{llccccc}
\hline Pre-test & 22 & 2,9079 &, 24019 & 42 & $-1,002$ &, 322 \\
Post-test & 22 & 2,9928 &, 31685 & & \\
\hline
\end{tabular}

When Table 7 is examined, it has been concluded that the students in the control group have an average pretest attitude score of $\mathrm{B}=2.90$ and an average post-test attitude score of $\quad \mathrm{B}=2.99$. Although the post-test attitude scores of the control group are higher than pre-test attitude scores, the difference between them is not statistically significant $(\mathrm{t}=-1,002, \mathrm{p}>0.05)$.

The t-test (Paried Samples t-test) has been used to determine whether there is a statistically significant relation between the pre-test attitude scores of the students in the experimental group and the post-test attitude scores obtained after 14 weeks of practice. The results of the t-test analysis, including pre-test and post-test attitude scores of the students in the experimental group, are shown in Table 8.

Table 8. Related sample results of t-test analysis of pre-test and post-test attitude scores of the students in the experiment group

\begin{tabular}{lllllll}
\hline Test & $\mathrm{n}$ & $\mathrm{B}$ & $\mathrm{S}$ & $\mathrm{sd}$ & $\mathrm{t}$ & $\mathrm{p}$ \\
\hline Pre-test & 28 & 2,9126 &, 21041 & 54 & $-2,503$ &, 015 \\
Post-test & 28 & 3,0752 &, 27176 & & & \\
\hline
\end{tabular}

When Table 8 is examined, it has been concluded that the students in the experimental group have an average pre-test attitude scores of $\mathrm{B}=2.91$ and post-test attitude scores of $\mathrm{B}=3.07$. When the results are examined, it ihas been seen that the average of the post-test attitude scores of the students in the experimental group is higher than the average of pre-test attitude scores and the difference between them is statistically significant in the post testdirection $(\mathrm{t}=-2,503, \mathrm{p}<0.05)$.

When the 14 weeks of implementaton is over, independent t-test (T-test) has been used to determine whether there is a significant difference between the post-test attitude scores of the experimental group and the control group in both of which different teaching methods have been applied. The results are shown in Table 9.

Table 9. Unrelated Sample t-test Analysis Results of Post-test Attitude Scores of Students in the Experimental Group and the Control Group

\begin{tabular}{lllllll}
\hline Group & $\mathrm{n}$ & $\mathrm{B}$ & $\mathrm{S}$ & $\mathrm{sd}$ & $\mathrm{t}$ & $\mathrm{p}$ \\
\hline Experimental & 28 & 3,0752 &, 27176 & 48 &, 989 &, 328 \\
Control & 22 & 2,9928 &, 31685 & & & \\
\hline
\end{tabular}

When Table 9 is examined, it has been concluded that the average attitude score of the students in the experimental group is $\mathrm{B}=3,07$ and the average attitude score of the students in the control group is $\mathrm{B}=2,99$. When the results are examined, it has been observed that the post test attitude scores of the students in the experimental group are higher than the post test attitude scores of the students in the control group, but this difference was not statistically significant $(t=0,989, \mathrm{p}>0,05)$.

Findings and Explications on the Third Problem of the Research 
The third question of the research is "Is there a meaningful difference between math achievement test scores of the experimental group and the control group students by gender. Data have been analyzed by Mann Whitney U-test (Mann Whitney U-test Independent Samples) for unrelated samples.

Before the research, mathematics achievement test has been applied as a pre-test to determine whether the students in the experimental group and the students in the control group are on equal footing. The Mann Whitney U-test (Independent Samples) has been used to determine whether there is a significant difference in scores the students in both groups get between the students in the experimental group and those in the control group by gender. The relation between pre-test achievement scores according to the gender of the students in the experiment group is shown in Table 10.

Table 10. Mann Whitney U-test Test Results of Pre-test Scores of the Students in the Experimental Group by Gender

\begin{tabular}{llllll}
\hline Gender & $\mathrm{n}$ & Mean Rank & Rank Sum & $\mathrm{U}$ & $\mathrm{p}$ \\
\hline Female & 12 & 16,08 & 193,00 & 77 &, 370 \\
Male & 16 & 13,31 & 213,00 & & \\
\hline
\end{tabular}

When Table 10 is examined, it has been concluded that pre-test success rank average of female students in the experimental group is $B=16,08$ and the pre-test success rank average of male students is $B=13,31$. When the results are interpreted, the difference between them is not statistically significant although the pre-test success scores of the male students in the experimental group are higher than the pre-test achievement scores of the female students $(\mathrm{U}=77, \mathrm{p}>0.05)$.

In this study, Mann Whitney U-test (Mann Whitney U-test Independent Samples) has been used to determine whether there is a meaningful relation between post-test achievement scores of the students in the experimental group by gender. The relation between the post-test success scores of the students of the experimental group by sex is shown in Table 11.

Table 11. Mann Whitney U-test Test Results of Post-test Scores of Students in the Experimental Group by Gender

\begin{tabular}{lccccc}
\hline Gender & $\mathrm{n}$ & Mean Rank & Rank Sum & $\mathrm{U}$ & $\mathrm{p}$ \\
\hline Female & 12 & 15,54 & 186,50 & 83,50 &, 558 \\
Male & 16 & 13,72 & 219,50 & \\
\hline
\end{tabular}

When Table 11 is examined, it has been concluded that the mean of the post test success rank averages of male students in the experimental group is $\mathrm{B}=13,72$ and that of post-test success rank average of female students is $\mathrm{B}$ $=15,54$. When the results are interpreted, it has been seen that there is not a statistically significant difference between the scores of female and male students in the experimental group after 14 weeks of implementation $(\mathrm{U}=$ $83,50, \mathrm{p}>0.05)$, although the post-test success scores of female students are higher than the post-test success scores of male students.

Before the implementation, the control group students who are learning mathematics in the constructivist learning environments of MoNE, the achievement test prepared by the researcher has been applied as pre-test. Data have been analyzed using Mann Whitney U-test (Mann Whitney U-test Independent Samples). The relation between pre-test achievement scores of the control group students according to the gender is shown in Table 12.

Table 12. Mann Whitney U-test Test Results of Pre-test Scores of Students in Control Group by Gender. 


\begin{tabular}{lccccc}
\hline Gender & $\mathrm{n}$ & Mean Rank & Rank Sum & $\mathrm{U}$ & $\mathrm{p}$ \\
\hline Female & 10 & 11,00 & 110,00 & 55 &, 736 \\
Male & 12 & 11,92 & 143,00 & & \\
\hline
\end{tabular}

When Table 12 is examined, it has been concluded that pre-test success rank average of male students in the control group is $\mathrm{B}=11,92$ and pre-test success rank average of female students is $\mathrm{B}=11,00$. When the results are interpreted according to Table 12 , the difference is not statistically significant $(U=55, p>0.05)$, although the male students in the experimental group after 14 weeks of practice have more post-test achievement scores than the female students in the experimental group.

The achievement test applied as a pre-test to the control group students who continue their lessons in the constructive classroom environment has been applied as a post-test at the end of the implementation. Data have been analyzed using Mann Whitney U-test (Mann Whitney U-test Independent Samples). The relation between post-test achievement scores of the control group students by gender is shown in Table 13.

Table 13. Mann Whitney U-test Test Results of PostTest Scores of Students in the Control Group by Gender

\begin{tabular}{lccccc}
\hline Gender & $\mathrm{n}$ & Mean Rank & Rank Sum & $\mathrm{U}$ & $\mathrm{p}$ \\
\hline Female & 10 & 11,15 & 111,50 & 56,5 &, 815 \\
Male & 12 & 11,79 & 141,50 & & \\
\hline
\end{tabular}

When Table 13 is examined, it can be seen that the post-test success average of the male students in the control group is $\mathrm{B}=11,79$ and the post-test success average of female students is $\mathrm{B}=11,15$.

When the results are interpreted, it has been seen that the male students who are in the control group after 14 weeks of practice are more successful than the female students, but the difference between them is not statistically significant. ( $\mathrm{U}=56,5, \mathrm{p}>0.05)$.

\section{Findings and Explications on the Fourth Problem of the Research}

The fourth question of the study is "Is there a significant difference between the pre-test and post-test attitude scores of the students in the experimental group and the control group according to gender?" Data have been analyzed by Mann Whitney U-test (Mann Whitney U-test Independent Samples) for unrelated samples.

The Mann Whitney U-test (Mann Whitney Utesti Independent Samples) results, which are used to determine whether there is a significant difference in terms of gender in the pre-test attitude scores of the students in the experimental group, are shown in Table 14.

Table 14. Mann Whitney U-test Test Results of Pre-test Attitude Scores of Students in the Experiment Group According to Gender

\begin{tabular}{|c|c|c|c|c|c|}
\hline Gender & $\mathrm{n}$ & Mean Rank & Rank Sum & $\mathrm{U}$ & $\mathrm{p}$ \\
\hline
\end{tabular}




\begin{tabular}{lccccc}
\hline Female & 12 & 15,79 & 189,50 & 80 & 471 \\
Male & 16 & 13,53 & 216,50 & \\
\hline
\end{tabular}

When Table 14 is examined, the pre-test attitude scores of male students in the experimental group have been found to be $\mathrm{B}=13.53$, and pre-test attitude scores of female students have been found to be $\mathrm{B}=15,79$. When the results are interpreted, the pre-test attitude scores of the female students in the experimental group have been found to be higher than the attitude scores of the male students in the experimental group, but there is no statistically significant difference between them $(\mathrm{U}=80,00, \mathrm{p}>0.05)$.

The results of the Mann Whitney U-test (Mann Whitney Utesti Independent Samples) used to determine whether there is a gender difference in post-test attitude scores of the students in the experimental group after the practice are shown in Table 15.

Table 15. Mann Whitney U-test Test Results of Post-Test Attitude Scores of Students in the Experimental Group by Gender

\begin{tabular}{lccccc}
\hline Gender & $\mathrm{n}$ & Mean Rank & Rank Sum & $\mathrm{U}$ & $\mathrm{p}$ \\
\hline Female & 12 & 13,08 & 157 & 79 &, 430 \\
Male & 16 & 15,26 & 249 & & \\
\hline
\end{tabular}

When Table 15 is examined, it has been observed that male students in the experimental group have post-test attitude scores average $X=15,26$ and post-test attitude scores of female students are $X=13,08$. When the findings are interpreted, the male students in the experimental group have more post-test attitude scores than the female students in the experimental group, but there is no statistically significant difference between them $(U=79.00, p$ > $0.05)$.

Pre-test attitude scores of the students in the control group have also been examined in terms of gender. The data Mann Whitney U-test (Mann Whitney U-test Independent Samples) are shown in table 16.

Table 16. Mann Whitney U-test Test Results of Pre-test Attitude Scores of Students in Control Group by Gender

\begin{tabular}{llllll}
\hline Gender & $\mathrm{n}$ & Mean Rank & Rank Sum & $\mathrm{U}$ & $\mathrm{p}$ \\
\hline Female & 10 & 8,40 & 84,00 & 29 &, 040 \\
Male & 12 & 14,08 & 169,00 & & \\
\hline
\end{tabular}

When Table 16 is examined, the pre-test attitude scores of the male students in the control group have been found to be $\mathrm{B}=14,08$ and the pre-test attitude scores of the female students have been found to be $\mathrm{B}=8,40$. The attitude test prepared by Duatepe and Kaygisiz (1999) has been applied as pre-test to the control group students who are educated in the constructivist learning environments of MoNE before the implementation. The data obtained have been analyzed by Mann Whitney U-test (Mann Whitney U-test Independent Samples) for unrelated samples. When the findings are examined, it has observed that there is a statistically significant difference in pretest attitude scores in direction of male students $(U=29.00, \mathrm{p}<0.05)$. 
In the study, the scores of the post-test attitudes of the students in the control group have also been examined in terms of gender. The data are presented in Table 17 for Mann Whitney U-test (Mann Whitney U-test Independent Samples) for unrelated samples.

Table 17. Mann Whitney U-test Test Results of Post-Test Attitude Scores of Students in Control Groups by Gender

\begin{tabular}{llllll}
\hline Gender & $\mathrm{n}$ & Mean Rank & Rank Sum & $\mathrm{U}$ & $\mathrm{p}$ \\
\hline Female & 10 & 9,25 & 92,50 & 37 &, 137 \\
Male & 12 & 13,38 & 16,50 & & \\
\hline
\end{tabular}

When Table 17 is examined, it has been observed that the post test attitude scores of male students in the control group are $X=13,38$ while post-test attitude scores of female students are $X=9,25$. Within the curriculum prepared by Ministry of Education based on constructivist approach, the lessons have been continued with the activities in the coursebook with the students of the control group. The attitude test, which was applied as a pretest, has been applied as a post test at the end of the research. The data obtained have been analyzed by Mann Whitney U-test (Mann Whitney U-test Independent Samples) for unrelated samples. In line with these findings, the average of male students in the control group is higher than that of female students, but no statistically significant difference has been observed between them $(U=37.00, p>0.05)$.

\section{Findings and Explications of the Fifth Problem of the Research}

The fifth problem of this research is "What are the opinions of students about teaching using gamification?" The findings of this research problem consist of unstructured interviews with students and notes taken by the researcher during the implementation. In the answers obtained from the students, different names have been given to the students in order to keep their identity confidential.

Students in the experiment group have been asked "How do you feel if there is interaction with other friends in the implementatiton?" They have said that they have given their attention to the game in order to watch their previous friends' games and to try to make better than them. In addition, many of the students have said that they helped their friends to finish the game.

The students have been asked "Do you have a competitive feeling in the course?" When the answers given by the students are examined, they have said that they try to earn more points than their friends won, watch all the friends' games and try to go them better by getting more points than their scores.

Students have been asked "are there any similarities between these courses that are normally held in the school and these practices" and "What are the similarities?" Students have expressed that they have had a lot of fun in practice, unlike the lessons that are normally taught and they have had no anxiety for learning. The common point with other practises is that at the end of both practises the questions can be solved easily.

Finally, students have been asked "Do you want all the lessons in school to be like this?" The students have expressed that they wanted all the lessons to be taught in this way. Thus, they have expressed that they are not tired from the lessons, their relationships with their friends are better and they are more active in this way than they are tired of sitting in class and listening to lessons.

\section{Discussion and Conclusion}

\section{Discussion and Conclusions on the First Problem of the Research}

The first problem of the study is "Is there a meaningful difference between the pre-test and post-test achievement scores of the experimental group and the control group students?" 
According to the findings obtained before the study, there was no statistically significant difference between pre-test achievement scores of control group students who were applied game-based learning method which is one of the active learning methods and MoNE structured learning method. When we look at this result, it can be said that the achievement levels and readiness of the students in the experiment and control groups are equal before the research. According to the findings obtained from the implementation, there is no statistically significant difference between the post-test success scores of the experimental group in which the game-based learning method, which is one of the active learning methods, has been applied, and the post-test success scores of the control group students in which the MoNE structured learning method has been applied.

According to the results of the research, it has been observed that teaching with game-based learning method is as successful as MoNE structured teaching method. As a result of the research, the reason why there has been no significant difference between the success scores of the students in the experimental group and the success scores of the students in the control group shows that students comprehend the subject while playing the games.

As a result of the research, although there is no significant difference between the achievement scores of the students in the game-based learning environments and the students in the MoNE structured learning environments, the benefits provided by the game-based learning environments to the learning process can not be denied. This result has parallelism with the results of studies done by Polat (2014) and Samur (2015) using the method of gamification in the literature.

In the light of the information obtained, despite the fact that both the gaming-based learning method and the MoNE structured teaching method have improved the mathematical achievement of the students, a statistically meaningful difference can not be obtained. The game-based learning method offers students the opportunity to learn by living (Aksoy, 2014). Students develop their problem solving skills (Doğusoy and İnal, 2006). It provides direct feedback in the actions for players and directs the students to find the right choice (Bayırtepe and Tüzün, 2007). Considering the advantages and disadvantages of the game-based learning method and the MoNE structured teaching method, it is seen that the use of digital computer games in lessons is positive for students..

\section{Discussion and Conclusions on the Second Problem of the Research}

The second problem of the study is "Is there a meaningful difference between the pre-test and post-test attitude scores of the experimental group and the control group students?"

According to the findings obtained before the implementation, there has been no statistically significant difference between pre-test attitude scores of the experimental group and control group students. This result shows that the attitudes of the students in the experimental group and the control group against the mathematics lesson are equal before the implementation. When the findings obtained at the end of the study have been examined, no significant difference has been observed between the pos-ttest attitude scores of the experimental group and the control group students.

When the findings obtained from the research are examined, it has been observed that the post-test attitudes of the students in the game-based learning environments and in the MoNE constructivist learning environments are similar. This case shows us that the attitudes of the students towards the courses do not change easily and that the attitudes have been around for a long time and will change over a long period of time. Since the attitudes of students to mathematics courses have existed from the past until now, it has not been possible to change it completely over a period of 14 weeks. When the results are examined, the attitude scores of the experimental group are higher than the control group, but a statistically difference has not occured. As the results are examined, if the educational digital games are used over a longer period of time, it can be said that students' attitudes towards mathematics lesson can increase.

When the attitude scores of the students are examined, it has been observed that while there is no significant difference between pre-test attitude scores and post-test attitude scores of the control group students, there is a significant difference between the pos-ttest attitude scores of the students in the experimental group. It can be inferred from this finding that the game-based learning methods applied in the experimental group positively increased the students' attitudes towards mathematics lesson. This conclusion has been reached both by the observations made during the implementation and after the implementation interviews. Students want to continue their classes in game-based learning environments that they enjoy and have fun. Also, in response to the question "Which lessons do you want to process using EBA games?", The students often pointed out that they would like to process the mathematics course with gamified game-based learning method. It has been seen that they want to 
use EBA games in general. As a result of the research, it has been observed that the attitude scores of the students in the experimental group have increased positively in 14 weeks. Students have enjoyed the game-based learning environments that they are active, entertain and enjoy in the lessons. These results show us that the attitude toward the mathematics course will be able to continue to increase positively when it is continued to be applied.

\section{Discussion and Conclusions on the Third Problem of the Research}

The third problem of the study is "Is there a meaningful difference between the achievement scores of the pretest and the post-test of the students in the experimental group and the control group according to gender?"

There is no statistically significant difference between the achievement scores of pre-test applied to students in the experimental and control groups and the achievement scores of post-test applied to students in the experimental and control groups. This result is similar to the results of the studies done in the literature (Yağı, 2007; Bayırtepe \& Tüzün, 2007; Annetta, et al., 2009; Malta, 2010; Brom, et al., 2011; Clark, et al., 2011, Korkusuz, 2012). This result has revealed that the teaching methods applied in the research do not affect the achievement scores of mathematics lessons by the fact that the students are girls or boys.

\section{Discussion and Conclusions on the Fourth Problem of the Research}

The fourth question of the study is "Is there a meaningful difference between the pre-test and post-test attitude scores of the students in the experimental group and the control group according to gender?"

There has been no significant difference between the post-test attitude scores of the control group and pre-test and post-test attitude scores of the experimental group according to gender. A significant difference has been observed only in the control group pre-test scores according to gender. When the results are examined in general, it has been observed that there is not a statistically significant difference between male and female students' attitudes towards mathematics lesson. The results obtained in the study show parallelism with the results of the study conducted by Şahin (2015) using the gamification method in literature.

Another point which is noteworthy in the survey, male students in the experimental group have lower pre-test attitude scores than female students, whereas scores of male students are higher than female students in post-test attitude scores. This may be due to the fact that computer games may have attracted more attention to boys than girls. Looking over in general, boys are more interested in computer games and everything in the digital world can attract their attention. This result has been reached through interviews with students. Male students in the interviews have said that these games are much easier than the games they play. Use of the game in the teaching environment can affect the attitudes of the students towards the mathematics course in a positive way as they express their enjoyment while playing.

\section{Discussion and Conclusions on the Fifth Problem of the Research}

The fifth question of the research is "What are the opinions of students about teaching using gamified gamebased learning?" At the end of the research, students' opinions about the implementation process were obtained with unstructured interviews. In these interviews made with the students, the answers of the questions have been interpreted.

In the interviews with students in the experimental group, it has been seen that there is a cooperation atmosphere among the students of game based learning environment. In order not to fall behind as a team, the students who are successful have helped students who are not successful. Peer education has also been introduced at this stage. The students who are successfull in the games have helped their friends who are not successfull in the games to learn. The students have stated that they have got the pleasure and the fun that they got from games from the lessons, too. Students have expressed that they are normally bored in mathematics classes, but when digital games have been used the lessons are fun. Students have expressed that they have lost track of time during the lessons.

In response to the questions asked to the students at the interviews held in the control group, they have often mentioned that they are very bored in mathematics classes. The mathematics course, which is quite abstract for the students in the concrete operational stage, is seen boring and monotone course in the perception of the students. Games made in this way will positively affect the attitudes and interests of the students towards the mathematics lesson. 
Today, the games in EBA are useful for lessons and are the greatest helpers to teachers in achieving the set goals. Thanks to this network that students can use in their homes, they are able to complete what they do not understand. Having the opportunity of playing games, solving questions and listening to a desired topic, EBA has become a frequently used network of students with these possibilities.

\section{Suggestions}

With the concept of gamification, which is a new concept in the literature, studies can be carried out in different learning areas and at different grade levels. The target acquisitions determined by MONE can be made more attractive by integrating game-based method used to motivate the students into the educational environments. Scientific studies can be carried out on EBA games at different levels of education and in different learning areas. Considering that the study period is 14 weeks, more specific results can be obtained especially if it is done with students in 5th, 6th, 7th and 8th grades. Due to limitations, this study has been conducted with 50 students. Other studies to be carried out can be more clear when it is done with more students. This research has been conducted in two schools whose socio-economic level can be considered as low. Similar studies can be carried out at different socio-economic levels. EBA games can be used frequently in elective mathematics lessons taught in schools. MONE can provide teachers with in-service training opportunities related to gamification so that teachers can improve themselves. Mathematics courses that are not often liked by students can be made favourite by activities like this. Before starting their career, teacher candidates in the education faculties can adopt these practices with games and activities that can be played in the digital environment.

\section{Acknowledgments}

It has been derived from the master thesis study called "The Effect Of Gamification Methodology On Students' Achievements and Attitudes Towards Mathematics". This study has been supported by Erciyes University Scientific Research Projects Unit, project code SYL-2016-6993. 


\section{Oyunlaştırma Yöntemiyle Öğrenmenin Öğrencilerin Matematik Başarılarına ve Derse Yönelik Tutumlarına Etkisi}

\section{Giriş}

Bilim ve teknoloji hızlı bir şekilde geliştiği için bilginin eskiden olduğu gibi geleneksel yöntemler kullanılarak aktarılması oldukça zordur. Bu durum göz önüne alındığında müfredat programlarında değişiklikler yapılarak özgür, yaratıc1, sorgulayan, karşılaştı̆̆ı problemlerin farkına vararak çözüm üreten, öz güveni yüksek bireyler yetiştirilmesi gerekmektedir. Buna göre öğrenciyi merkeze alan, öğrencilere kendilerini özgür hissedecekleri bir eğitim ortamı hazırlanmalıdır. Dünyadaki tüm ülkelerin birbirlerini takip etmesine paralel olarak, eğitimde de yeni arayışlar içerisine girilmiştir.

Bilgi ve iletişim teknolojileri (BİT) sürekli değişkenlik gösteren bir yapıdadır. Her gün bu alanda gerçekleşen yenilikler ve değişikliklerin yaşamımıza girmesi bu alanın eğitimde de yoğun olarak kullanılmasına sebep olmaktadır. Bu durum göz önüne alındığında, ülkelerin eğitim sisteminde yapacakları değişikliklerde teknolojiyi eğitim öğretime dahil etmeleri kaçınılmazdır. Bu sonuç doğrultusunda ülkelerin eğitim teknolojilerine yaptıkları yatırımlar artmıştır ve artarak da devam etmektedir. Eğitimde kullanılan teknoloji sayesinde eğitim öğretim ortamlarına bilgisayarlar, tabletler, akıllı tahtalar girmiştir ve sayısı gün geçtikçe artmaktadır. Akıllı tahtalar son yıllarda öğretmenlere ders anlatımı konusunda çeşitli kolaylıklar sağlamaktadır. Bu tahtalar; yazı, ses, video gibi unsurları kullanarak hem zaman tasarrufu sağladığı, hem de farklı öğrenme sitillerine hitap ettiği için tercih edilmektedir.

Bilgisayarın motive ediciliği ve öğrenciler açısından ilgi çekiciliği düşünüldüğünde MEB'in öğrenciler için belirlediği hedeflere ulaşabilmek için eğitsel dijital oyunlar kullanılabilir. Akıllı tahtalarda internet kullanımı ile birlikte öğrencilere çok çeşitli imkanlar sunulabilir hale gelinmiştir. Görsel düzeyde sunulan materyaller öğrencilerde daha kalıcı öğrenmeyi sağlamakla birlikte derslerin zevkli ve daha verimli işlenilir hale gelmesine olanak sağlamıştır. MEB 'in yakın zamanda tüm öğretmenlerin ve öğrencilerin hizmetine sunduğu EBA(Ĕ̆itim Bilişim Ağı); konu anlatımı, uygulama ve oyun yönünden zengin olup derste rahat şekillerde kullanmaları için öğretmenlerin hizmetine sunulmuştur.

Oyunlaştırma, öğrencinin derse olan motivasyonunu, performansını ve ders sürecindeki katılımını en üst seviyeye çekebilmek için, oyun dışındaki oyun bileşenlerinin kullanılmasıdır. Oyunlaştırmanın temelinde motivasyon vardır ve oyun bileşenleri sayesinde sağlanan dışarıdan gelen motivasyonun kişi tarafindan içselleştirilmesini amaçlamaktadır. Karabacak (1996) 'ya göre öğrenmeyi sağlamanın ilk basamağını ilgi uyandırma, dikkati sağlama ve güdülemedir. Bu amaçla öğretim faaliyetlerinde oyunla öğretimden yararlanılması gerektiğini söylemektedir. Yapılan araştırmalarda Şahin (2015) öğrencilere kaliteli bir öğrenme ortamı sağlayabilmek için öğrenme hedeflerinin oyun bileşenleri ile birlikte verilmesinin ilgi çekici olacağını ve öğrencilerde anlamlı öğrenmelerin gerçekleşmesini sağlayabileceğini vurgulamaktadır. Oyunların öğrencilere sunduğu rekabet, eğlence, heyecan gibi eğitimi kaliteli hale getirebilecek olumlu bileşenler yardımı ile aktif öğrenme gerçekleşebilmektedir.

Türk Dil Kurumu'nun yaptığı oyun tanımında oyunun zeka ve yetenek geliştirici, belirli kurallara sahip, kişilerin iyi vakit geçirmesine yardımcı bir araç olduğundan bahsedilmektedir. Oyun oynamak çocukların temel ihtiyaçları gibi en tabi gereksinimlerindendir. Çocuklar, gençler, yaşlılar eğlenebilmek için doğumdan ölüme kadar oyun oynarlar. Bebekler doğdukları andan itibaren çevrelerindeki, o küçük dünyalarındaki her şey bir oyundan ibarettir. Çocuklar ilerdeki karakterlerine, duruş ve davranışlarına oyunlardaki kişilikleri yardımı ile hazırlanır. Birden fazla kişiyle oynanan oyunlarda oyuna katılan diğer kişilerle olan iletişim sosyal hayata girişin başlangıcıdır. Kişiler için eğlenceli bir etkinlik olan oyunlar, çocukların zihinsel gelişimlerinde ve öğrenmelerinde oldukça önemli bir yere sahiptir. Şahin (1998) e göre oyun oynayan çocukların problem çözme becerileri de gelişmektedir. Bu durum sonucunda oyunların öğretim programına girmesi kaçınılmaz olmuştur.

Günümüzde eğitim anlayışı öğretmenin gerekli olan tüm bilgiyi öğrenciye aktardığı, ezberci, öğrencilerin sadece öğretmeni dinleyip onun gösterdiği yoldan çıkmadığı, öğretmen merkezli anlayıştan uzaklaşarak öğrencinin sorular sorduğu, aktif olduğu, öğretmenin sadece öğrencilerin ihtiyaçları doğrultusunda onları yönlendirdiği, öğrencinin doğruyu kendisinin bulduğu, öğrenciyi merkez alan bir duruma gelmiştir. Geleneksel yöntemlerin uygulandığı eğitim öğretim ortamlarında anlamadan çok ezberci eğitim söz konusu olduğu için günümüzdeki toplum ihtiyaçlarını karşılamak için yetiştirilen bireylerin eğitimine yeterli gelmemeye başlamıştır. İçinde bulunduğumuz zamanda toplumun gereksinimlerini karşılamada eksik kalan geleneksel öğretim yöntemleri bir 
kenara bırakılarak, çocukların eğlenmesine olanak tanıyan, eğlenerek öğrendikleri oyun, eğitim ortamında kullanıldığında, öğrenme ortamı daha eğlenceli olur ve aynı zamanda Milli Eğitim Bakanlığı tarafından belirlenen hedef ve kazanımlara ulaşmada daha sağlam adımlarla ilerlenen bir yol seçilmiş olur. Şahin (2015) tarafından yapılan çalışmada da eğitsel oyunlarla yapılan eğitim öğretimin en az geleneksel yöntemlerle yapılan eğitim öğretim kadar faydalı olduğu görülmüştür.

Bu alanda Tüzün (2006) tarafindan yapılan çalışmada öğrencilerin çok eğlendikleri ve isteyerek katıldıkları oyunların, sınıf ortamlarında kullanılmasının göz ardı edilemeyecek bir konu olduğu ve öğrencilerin eğlendikleri oyunların öğretim ortamlarını da sıkıcılıktan kurtararak eğlenceli hale getirdiği belirtmektedir. Oyunların, gönüllülük esasına dayandığı ve öğrencileri eğlendirdiği düşünüldüğünde, sınıf ortamlarında kullanılacak dijital oyunlar ulaşılmak istenen hedef ve kazanımları daha ulaşılabilir hale getirebilir. Eğitimde geçen genel bir tabir olan "eğlenemezlerse öğrenemezler" sözünden yola çıkarak oyunlarla devam ettirilen eğitim ortamlarında öğrenme daha hızlı ve kalıcıdır. Bunun yanında sınıf içinde oynatılacak tamamlayıcı oyunlar öğretimin alternatifi ve zenginleştiricisi olabilir.

Oyunlar tam olarak kazanıma uygun hazırlandığında öğrenciler için eğitici bir ortamın temel taşı olur. Eğitsel oyunlar aynı zamanda öğrencilerde matematik dersi adına oluşması en çok istenen özellik olan problem çözme becerisinin gelişmesine büyük katkı sağlar. Eğitsel oyunlarla öğrenciler sı̆̆ düşünmekten kurtularak dünya sorunlarını tartışır hale gelebilir ve öğrencilerin yaşam hakkında bir fikir sahibi olmaları sağlanabilir. Öğrencileri sıkan, zor gelen konular eğitsel oyunlar sayesinde zevkli, kolay anlaşılır hale gelebilir. Eğitsel oyunlar hazırlanırken yeni verilecek kazanımlar eski bilgiler ile birlikte ortaya konursa eski bilgiler yeni oluşacak bilgilere basamak görevi görecektir. Eğitsel oyunlar sayesinde eski bilgiler sıkılmadan tekrar edilebilir. Derste pasif kalan, utanan, çekinen öğrencilerin derse katılması sağlanır. Bu şekilde öğrenme farklı seviyelerdeki tüm öğrencilerde gerçekleşebilir. Eğitsel oyun sayesinde öğrencilerin derse istekleri arttırılarak derse ilgi duymaları sağlanır. Böylece öğrencilerde yeterlilik duygusu artar ve akabinde gelen başarı derse olan motivasyonu artırır. Oyunlar sadece derste pratik yapmak değil, okul sonrasında da pratik yapmaya olanak sağladığı için eğitim öğretim ortamında oyunun önemi tartışılmazdır.

Öğrencilerin oyun oynayarak öğrenmesi temel alınarak geliştirilen oyun temelli öğrenme, oyunun içerisine oyun problemleri yerleştirilerek, öğrencilerin kendi buldukları veya oyun içerisinde keşfettikleri çözümler ile istenilen hedefe ulaşmaları için hazırlanan öğretim ortamlarıdır. Yapılandırmacı yaklaşımda olduğu gibi oyun temelli öğrenme ortamlarında da öğrenci hedef davranışa kendinde var olan bilgilerle kendisi ulaşır, eski bilgileri ve ulaştığı yeni bilgileri kıyaslar, yeni ve farklı çözümler üretmek için var olan bilgisinin üzerine yeni bilgilerini ekler. Bu sayede öğrenci kendi bilgisini yapılandırmış olur. Buradan da anlaşıldığı gibi, oyun temelli öğrenme ortamlarında öğrenci ezberden uzak kendinde var olanla yola çıkıp yeni bilgiyi de araştırma ve sorgulamaya dayandırarak gözlem yoluyla edinir. Bu durumu destekleyen çalışmalardan birisi Aksoy (2014)'dur. Yapılan bu çalışma öğrencilerin bilgiyi kolayca elde edebilecekleri butonlar bulunmasına rağmen, bilgiye ulaşabilmek için ellerinden gelen gayreti gösterdikleri ve farklı çözümlerle çözüm yolları aradıkları görülmüştür. Bu bilgiler 1şığında oyun temelli öğrenmenin öğrencilerin öğrenme durumlarına olumlu etkiler sağlayabileceği söylenebilir. Literatür taraması yapıldığında çalışmalardan bazılarında da benzer sonuçlar görülmektedir (Korkusuz, 2012; Sönmez \& Dinç, 2011; Aksoy, 2014).

Eskiden sokak ortamında olan oyunlar bilim ve teknolojideki gelişmeler ile birlikte dijital ortamlara taşınmıştır. Oyunlar artık tablet, bilgisayar, cep telefonu, oyun konsolları gibi teknolojik aletlerle yaygın olarak oynanmaya başlamıştır. Yapılan araştırmalarda öğrencilerin zamanını artık sokak oyunlarından çok dijital oyunlarla geçirdiği ve bunun gün geçtikçe daha da arttığı gözlemlenmiştir. Bu konu üzerinde yapılan Güneş (2010) 'in çalışması incelendiğinde, dijital ürünlerin öğrenciler tarafından oyun oynamak için kullanıldığı ve öğrencilerin haftalık ortalama oyun oynamak için ayırdıkları vaktin ortalama üç saat olduğu görülmüştür. Bilgisayar oyunlarına artan ilginin ve ayrılan sürenin her geçen gün artığı göz önüne alınırsa MEB tarafından belirlenen özel ve genel hedeflere ulaşmak için bilgisayar oyunlarından faydalanabiliriz (Akpınar, 1999). Çetin (2013) bilgisayar oyunlarının sunmuş olduğu zengin uyarıcılar ve çeşitli problem senaryoları, öğrencilere eğlenceli zihinsel aktiviteler sağlayarak öğrencilerin bilişsel gelişimine katkı sağlayacağını belirtmektedir. Böylece bilgisayar başında oyun oynayarak saatlerini harcayan ve bu oyunları oynamaya son derece istekli olan öğrencilerin dezavantajları eğitsel dijital oyunlar sayesinde avantaja dönüştürülebilir.

Dijital ortamda öğretmen ve öğrencilere yardımcı olmak amacıyla ortaya çıkarılan Eğitim Bilişim A ğı (EBA), Yenilik ve Eğitim Teknolojileri Genel Müdürlüğü tarafından öğretmenlerin ve öğrencilerin kullanımına ücretsiz 
olarak sunulmuş çevrimiçi bir sosyal eğitim platformu (Eğitim Bilişim Ağı, 2016) olarak kullanılmaktadır. İçerisinde birçok eğitim hizmetinin yer aldığı EBA, günümüzde ilköğretim ve ortaöğretim öğrencileri ve öğretmenler tarafindan oldukça yoğun bir şekilde kullanılmaktadır. EBA 2012 yılında yayın hayatına başlamıştır. Değişen gereksinimlerle yenilerek zenginleştirilmiş ve dünyanın en büyük içerik hizmet veren sistemi haline gelmiştir (Hürriyet Gazetesi, 2016). 2015-2016 eğitim öğretim yılında EBA sistemi 10 milyon ilköğretim ve ortaöğretim öğrencisi tarafından kullanılmaktadır (Milliyet Gazetesi, 2016). Günümüzde artarak devam etmektedir.

EBA şu an da akıllı tahtanın var olduğu tüm okullarda yeni kurulan internet alt yapısıyla öğrenciler ve öğretmenlerin kolay bir şekilde kullanmasını amaçlayan MEB'in hizmetidir. EBA öğretmenlere ders anlatımında bir çok kolaylık sağlarken, öğrencilere konuları somutlaştırma, konu anlatımı, uygulama, oyun ve test yönünden de bir çok imkân sunmaktadır. EBA ile dersi işleyen bir öğretmenin işi hem daha kolay hem de daha zevkli bir hal almıştır. Okullarda kullanılmaya teşvik edilen EBA oyunları ile öğrenciler artık eğlenirken öğrenir duruma gelmişlerdir. Öğrencilerin okul dışında arkadaşlarıyla oynadıkları, yarıştıkları, heyecan dolu oyunlar okul ortamına taşınmış aynı zamanda ek bir zahmet harcamadan bu oyunları oynarken öğrenciler konuya hakim olmuştur. Aynı zamanda EBA ile öğretmenler birbirleriyle bilgi paylaşımları yapabilmekte, derste kullandıkları eğitici materyalleri, oyunları, anlatımları, birbirleriyle kolay bir şekilde paylaşabilmektedir.

Literatürde bu alanda yapılan son çalışmalar incelendiğinde, Kibar (2006), Kablan (2010), Sönmez ve Dinç (2011), Korkusuz (2012), Aksoy (2014) 'un çalışmalarında oyun temelli öğrenme ile geleneksel yönteme dayalı sınıf ortamlarının başarı durumları karşılaştırılmıştır. Bu çalışmalar incelendiğinde oyun temelli sınıf ortamındaki öğrenci başarısının geleneksel sınıf ortamındaki öğrenci başarısından daha fazla olduğu görülmektedir. Bundan farklı olarak Obet (2005), Güneş (2010), Kula ve Erdem (2006), Malta (2010)'un çalışmalarında ise oyun temelli öğretim yönteminin kullanıldığ 1 sınıf ortamının başarı durumu ile geleneksel öğretim yönteminin kullanıldığı sınıf ortamının başarı durumu karşılaştırıldığında anlamlı bir fark bulunamamıştır. Fakat oyun temelli öğretim ortamında bulunan öğrencilerin oldukça eğlendikleri, oyunların derslerde kullanılmasının öğretim ortamının çeşitliliğini arttırarak öğrencilere daha kaliteli eğitim ortamı sunacağını belirtmişlerdir. Yapılan araştırmalarda dikkat çeken başka bir nokta ise sınıf ortamlarının oyun oynandığında öğrencilerin ilgisini çektiği, derse karşı olan motivasyonlarını arttırdığıdır.

Çalışma Niğde ili Çiftlik ilçesi'nde ortaokulda 5. sınıfta öğrenim gören 50 öğrenci ile sınırlıdır. Araştırma, 5.sınıf "Kesirler" ünitesinin kazanımları ile sınırlıdır. Araştırma bulguları deney ve kontrol grubuna uygulanan matematik başarı testi ve matematik tutum testi ile sınırlıdır.

\section{Araştırmanın Amacı}

Bu çalışmanın amacı, ortaokul 5. sınıf matematik dersi "Kesirler” ünitesini geleneksel öğretim yöntemlerinden farklı olarak yeni oluşturulan Eğitim Bilişim Ağındaki oyunlar ve uygulamalar kullanılarak oyunlaştırılmış oyun temelli öğrenme ortamlarındaki akademik başarılarına, tutumlarına etkisini incelemektir.

\section{Araştırmanın Önemi}

Günümüzdeki bilim ve teknoloji çağında toplumun her kesiminde, her alanında olduğu gibi eğitim sisteminde de değişim kaçınılmazdır. Bu durum göz önüne alındığında öğretmen merkezli eğitimden öğrenci merkezli eğitime, geleneksel eğitim sisteminden yapılandırmacı eğitim sistemine doğru geçiş başlamıştır. Öğrenci yapılandırmacı eğitim yaklaşımı sayesinde kendi bilgilerini kendisi bulmakta ve yaşadığı ortamlarda sunulan farklı deneyimlerle öğrenci bilgiyi özümseme firsatı yakalamaktadır. Eğitimde teknoloji kullanımı öğretim yöntemlerinin yetersizliğini büyük ölçüde tamamlamakta ve yeni imkanlar sunmaktadır. Sürekli gelişen bilim ve teknoloji ile birlikte öğretim ortamlarındaki alternatif yolların sayısı çoğalmış ve bunun sonucu olarak eğitim programlarındaki değişiklikler kaçınılmaz olmuştur. Bu sebeple Milli Eğitim Bakanlığı (MEB) tarafından 2005 2006 eğitim öğretim yılı sonunda uygulanmakta olan müfredat yenilenmiş ve ülkenin her yerinde yapılandırmacı yaklaşım uygulamaları başlamıştır. Eğitimdeki değişimler sonucu matematik dersi de ezber bir ders olmaktan çıkıp yapılandırmacı yaklaşımlar sonucunda daha anlaşılır bir hal almayabaşlamıştır.

Öğrencilerin bilgisayar oyunlarına karşı olan ilgi ve isteklerini öğrenmeye yönelik olarak kullanılması günümüzde bir çok araştırmaya konu olmakta ve çocukların gelişimde oyunların önemli bir yere sahip olduğu araştırma sonuçlarında ortaya çıkmaktadır. Whelan (2005) oyun tabanlı öğrenmenin eğitim öğretim ortamlarını büyük ölçüde etkilediğini savunan eğitimcilerin ve araştırmacıların sayısının gün geçtikçe arttığını dile getirmektedir. Buna bağlı olarak oyunların eğitim ortamlarında artış göstereceğini düşünen Gee (2003) iyi bir 
şekilde tasarlanan video ve bilgisayar oyunlarının içerisindeki hayali dünyada insanların kendilerini başka bir şekilde yaratması eğlenmenin yanında öğrenmenin de gerçekleşmesini sağladığını belirtmiştir. Kirriemuir ve McFarlane (2004) oyunlar sayesinde insanların planlama, iletişim gibi beceriler edindiğinin altını çizmektedir. Shaffer, Spuire, Halverson ve Gee (2005) diğer araştırmacılara benzer şekilde video oyunlarının insanlarda sosyal ve kültürel alanda dünyalar oluşturduğunu, bunun da düşünme, teknoloji ve sosyal iletişimi kullanarak kişilerin öngörmesine fayda sağladığını belirtmektedir.

Matematik insanların zihinlerinde var olan bir sistem olduğu için soyut varlıklar ve bu varlıkların birbirleri ile olan ilişkilerini incelemektedir. Matematik tümdengelim yolunu kullanarak sayılar, geometrik şekiller, uzaylar vb. gibi soyut kavramlarda olan özellikleri ve bunların birbirleri ile arasında olan ilişkileri inceleyen bilim dalına verilen isimdir. Matematik bağlantılar ve yaptığı yorumlar yolu ile insanların hayatına kolaylık sağlayan bir bilimdir.

Matematik, kişilerde var olan yeteneklerin ortaya çıkarılmasında, yönlendirmeler yapılmasında, sistemli ve akla yatkın düşünce alışkanlıklarının öğretilmesinde amaçtır. Bu sebeple eğitim ile alakalı yapılan tüm yenileme çalışmalarında en önemli amaç, öğrenciler tarafından matematiğin anlaşılmasını kolaylaştıracak bir eğitim sisteminin oluşturulmasıdır. Matematik insan hayatında bu kadar önemli bir yere sahip olmasına rağmen öğrenciler tarafından sevilmemekte, öğrenciler tarafından sıkıcı bulunmakta, elle tutulup gözle görülmeyen bir ders olduğu düşünülmektedir. Ülkemizde birçok öğrenci matematiğin başarılması zor bir ders olduğunu düşünerek matematik dersine ön yargı ile yaklaşmaktadır. Öğrencinin başaramayacağı hissine kapılması dersten daha çok uzaklaşmasına ve alt yapıda büyük eksikliklere neden olmaktadır. Eğitimde son zamanlarda yapılan çalışmalar dersin soyut ve sıkıcı olması ön yargısını yıkmayı amaçlamaktadır (Yenilmez \& Dereli, 2009). Matematik korkusu, ögrencilerde ilkokuldan itibaren başlayan ve ileriki zamanlarda yıkılması çok zor olan bir ön yargıdır. Oynanan oyunlarla, gerçek yaşamdan kesitlerle, materyallerle anlatılan matematik dersinin öğrenciler için daha somut ve eğlenceli bir hale getirilmesi amaçlanmaktadır. Freud oyunu, çocuklara istediklerini gerçekleştirmelerine ve kaygı veren olayların üstesinden gelmelerine uygun ortam sağlamak için araç olarak görmüştür. Öğrenciler matematik dersini somut olarak gözlemleyebildiği, yaşamda matematiğin yerini fark etmeye başladığı anda ve dersi anlamasından dolayı derste aktif olmaya başladığı için matematik dersini sevmeye başlamakta buna bağlı olarak da matematik başarısı artmaktadır.

Oyun, oyuncunun bir dizi kurallar çerçevesinde kendisinden istenilen görevleri yerine getirdiği bir sistemdir. Oyun temelli öğrenme ortamlarında kavram, ilke ve problemler oyun senaryosu içerisinde öğrencilere sunulmaktadır. Oyun esnasında çözüm yolları üretilirken bir taraftan oyunda hakim olan konular tam olarak anlaşılarak diğer taraftan öğrencilerin eğlenmesi sağlanmaktadır.

\section{Araştırma Problemi ve Alt Problemler}

$\mathrm{Bu}$ araştırmanın ana problemi, “Oyunlaştırma yöntemiyle öğrenmenin öğrencilerin matematik dersi başarılarına ve derse yönelik tutumlarına etkisi nedir?” olarak belirlenmiş olup araştırmanın alt problemleri aşağıdaki gibidir:

1. Deney grubu ve kontrol grubu öğrencilerinin ön test, son test başarı puanları arasında anlamı bir farklılık var midir?

2. Deney grubu ve kontrol grubu ögrencilerinin ön test ve son test tutum puanları arasında anlamlı bir fark var midir?

3. Deney grubu ve kontrol grubu öğrencilerinin ön test, son test başarı puanları arasında cinsiyete göre anlamlı bir farklılık var midir?

4. Deney grubunda ve kontrol grubunda bulunan öğrencilerin ön test ve son test tutum puanları arasında cinsiyete göre anlamlı bir farklılık var midır?

5. Oyunlaştırma yöntemiyle yapılan öğretim hakkında öğrenci görüşleri nelerdir?

\section{Yöntem}

\section{Araştırma Modeli}

$\mathrm{Bu}$ çalışma ile; ortaokul 5. sınıf öğrencilerine uygulanan oyunlaştırma yöntemi ile yapılan öğretimin, öğrencilerin matematik dersi başarılarına ve matematik dersine karşı olan tutumlarına etkisi araştırılmaktır. Bu 
amaç kapsamında bu çalışmada nicel ve nitel araştırma yöntemlerinin birlikte kullanıldı̆̆ karma desenlerden gömülü desen kullanılmıştır. Nicel araştırma desenleri kullanılarak elde edilen bulguların nitel araştırmalarla desteklendiği yönteme gömülü desen adı verilir (Büyüköztürk vd., 2008). Bu desenin tercih edilme sebebi toplanan bu nicel verilerin nitel veriler ile desteklendiğinde daha geniş kapsamlı sonuçlar ortaya koymasıdır.

Nicel araştırma yöntemi olarak deneysel araştırma modellerinden biri olan ön test- son test kontrol gruplu yarı deneysel desen kullanılmıştır. Uygulama yapılacak olan okullarda bulunan sınıfların uygulama yapılmadan önce belirlenmesi ve tarafsız olarak belirleme şansının bulunmamasından dolayı bu model tercih edilmiştir. $\mathrm{Bu}$ desende belirlenen grupların ikisi de belirli değişkenlere göre eşleştirilmeye çalışılırlar. Eşleştirilen gruplar uygulama gruplarına tarafsız olarak seçilirler. Ancak, bu eşleştirme çalışma yapılacak grupların eşit seviyede olduğunun garantisini vermez. Bu ciddi bir sınırlılıktır. Fakat seçim yapılma şansının olmadığ durumlarda alternatif olarak kullanılacak bir desendir. Yarı deneysel desen yönteminin kullanılmasındaki amaç gruplardan birindeki değişim ile diğerindeki değişim arasında ne kadar fark olduğunu test etmektir. Yapılan araştırmada hem deney grubunda bulunan hem de kontrol grubunda bulunan ögrencilere, uygulamanın başında ve sonunda, sonunda matematik akademik başarı testi ön test ve son test olarak uygulanmıştır. Duatepe ve Çilesiz (1999) tarafından hazırlanan matematik dersi tutum ölçeği ön test ve son test olarak uygulanmıştır. Buna bağlı olarak 50 öğrencinin akademik başarılarında ve matematiğe karşı tutumlarında meydana gelen değişimler incelenmiştir.

\section{Örneklem ve Çalışma Grubu}

2016-2017 eğitim öğretim yılı bahar döneminde, Niğde ili çiftlik ilçesinde bulunan iki devlet okulunun 5. sınıf öğrencilerinden oluşan bir çalışma grubu belirlenmiştir. Çalışmanın deney grubunda, oyunlaştırılmış oyun temelli öğrenme ortamları ile eğitim yapılan sınıfta 28 öğrenci, geleneksel öğretim ortamında öğrenim gören 22 öğrenci ise kontrol grubunda olmak üzere toplamda 50 öğrenci bulunmaktadır.

Yapılan araştırmada uygun örneklem yöntemi kullanılmıştır. Farklı okullarda bulunan 5. sınıfların birisi deney grubu diğeri ise kontrol grubu olarak belirlenmiştir.

\section{Veri Toplama Araçları}

Araştırma 2016-2017 öğretim yılı bahar döneminde Niğde ili Çiftlik ilçesinde bulunan 5. sınıf öğrencileri ile yürütülmüştür. Bu öğrencilerden 28 öğrenci deney grubunda, 22 öğrenci kontrol grubunda bulunmaktadır. Uygulama haftada 2 ders saati olmak üzere 14 hafta boyunca devam etmiştir. Araştırma süresi 28 saat ile sınırlıdır. Araştırma süresinin 28 ders saati olması Eğitim Bilişim Ağındaki oyunların dijital eğitsel oyunlarla matematik öğretimine uygun olarak tasarlanmasından kaynaklanmaktadır. Daha önceleri matematik dersi adına kullanılacak eğitsel dijital oyunların sayısı az iken EBA sayesinde bu sayı artış göstermiştir..

Araştırmanın teorik kısmı ile ilgili veriler ve dayanaklar, problem cümlesi ile ilgili literatür taranarak elde edilmiştir. Araştırmanın nicel verilerini elde etmek için çeşitli ölçme araçları kullanılmıştır. Araştırmada kullanılan ölçme araçları;

Matematik başarı testi. Kontrol ve deney grubu öğretmenleri tarafından uzman görüşleri alınarak hazırlanan 20 sorudan oluşan çoktan seçmeli başarı testi, öğrencilerin "Kesirler” ünitesindeki akademik başarılarına anlamlı bir etkisi olup olamadığını belirlemek amacıyla kullanılmıştır. Bu araştırmada çoktan seçmeli test kullanılmasının nedeni; çoktan seçmeli testlerin ölçülmek istenilen kapsamı daha iyi örneklemesi, puanlanmanın objektif olması, çözülecek problemleri daha iyi ifade etmesi ve ölçümdeki şans hatasını azaltması (Öncü, 2003) gibi faydalarının bulunmasidir.

Akademik başarı testi ortaokul 5. sınıf matematik dersi öğretim programındaki "Kesirler" ünitesinin amaçları ve öğrenci kazanımları göz önüne alınarak hazırlanmıştır. Kazanımlar;

- Birim kesirleri sayı doğrusunda gösterir.

- Tam sayılı kesrin, bir doğal sayı ile bir basit kesrin toplamı olduğunu anlar ve tam sayılı kesri bileşik kesre, bileşik kesri tam sayılı kesre dönüştürür.

- Paydaları eşit veya birinin paydası diğerinin katı olan kesirleri sıralar.

- Bir çokluğun istenen basit kesir kadarını ve basit kesir kadarı verilen bir çokluğun tamamını birim kesirlerden yararlanarak hesaplar. 
- Sadeleştirme ve genişletmenin kesrin değerini değiştirmeyeceğini anlar ve bir kesre denk olan kesirler oluşturur.

- Birim kesirleri sayı doğrusunda gösterir.

- Paydaları eşit veya birinin paydası diğerinin katı olan iki kesrin toplama ve çıkarma işlemini yapar ve anlamlandirır.

- Ondalık gösterimlerin kesirlerin farklı bir ifadesi olduğunu fark eder ve paydası 10, 100 ve 1000 olacak şekilde genişletilebilen veya sadeleştirilebilen kesirlerin ondalık gösterimini yazar ve okur.

- Ondalık gösterimde virgülün işlevini, virgülden önceki ve sonraki rakamların konumlarının basamak değeriyle ilişkisini anlar; ondalık gösterimdeki basamak adlarını belirtir.

- Ondalık gösterimleri verilen sayıları sayı doğrusunda gösterir.

- Ondalık gösterimleri verilen sayılarla toplama ve çıkarma işlemleri yapar.

- Paydası 100 olan kesirleri yüzde sembolü (\%) ile gösterir.

- $\quad$ Bir yüzdelik ifadeyi aynı büyüklüğü temsil eden kesir ve ondalık gösterimle ilişkilendirir; bu gösterimleri birbirine dönüştürür.

- Kesir, ondalık ve yüzdelik gösterimle belirtilen çoklukları karşılaştırır.

Kazanımlara uygun olarak önce ortaokul 5. sınıf "Kesirler” ünitesi kazanımlarını içeren kaynaklardaki sorular incelenmiş ve araştırma testi oluşturulmuştur.

Tablo 1. Başarı Testi Madde Analizi

\begin{tabular}{ccc}
\hline & Madde Güçlüğü (P) & Madde Ayırt Ediciliği (R) \\
\hline Soru 1 & 0,86 & 0,35 \\
Soru 2 & 0,40 & 0,35 \\
Soru 3 & 0,60 & 0,42 \\
Soru 4 & 0,40 & 0,42 \\
Soru 5 & 0,84 & 0,64 \\
Soru 6 & 0,42 & 0,35 \\
Soru 7 & 0,76 & 0,35 \\
Soru 8 & 0,56 & 0,64 \\
Soru 9 & 0,40 & 0,42 \\
Soru 10 & 0,58 & 0,35 \\
Soru1 & 0,40 & 0,57 \\
Soru 12 & 0,40 & 0,42 \\
Soru 13 & 0,42 & 0,35 \\
Soru 14 & 0,42 & 0,42 \\
Soru 15 & 0,40 & 0,35 \\
Soru 16 & 0,42 & 0,42 \\
Soru 17 & 0,56 & 0,42 \\
Soru 18 & 0,40 & 0,42 \\
Soru 19 & 0,40 & 0,42 \\
Soru 20 & 0,72 & 0,35 \\
Ortalama & 0,51 & 0,42 \\
\hline
\end{tabular}

Elde edilen bulgular ile testin güvenilirliği KR-20 ile hesaplanmış testin iç tutarlılık anlamındaki güvenilirliği 0.60 olarak bulunmuştur; ortalama madde güçlük değeri 0,51 ; testin ortalama ayırt edicilik değeri 0.42 olarak bulunmuştur. Oluşturulan başarı testinde doğru sorular 1 puan, yanlış sorular ve boş sorular ise 0 puan olacak şekilde değerlendirilmiştir. Öğrenciler akademik başarı testinden en fazla 20 en az ise 0 puan alarak değerlendirilmişlerdir. 
Matematik dersi tutum ölçeği. Öğrencilerin matematik dersine karşı olan tutumlarını ölçmek amacıyla Duatepe ve Çilesiz (1999) tarafından geliştirilen "Matematik ile İlgili Tutum Ölçeği” kullanılmıştır. Bu tutum ölçeği öğrencilere ön test ve son test olarak iki kez uygulanmıştır. Tutum ölçeği güvenirlik testi SPSS'de yapılmış ve ön test sonuçları değerlendirildiğinde Cronbach's Alpha değeri 0,887 olarak bulunmuştur. Bu sonuç tutum testinin güvenilir olduğunu göstermektedir.

Yapılandırılmamış görüşme. Öğrencilerin yapılan uygulama hakkında görüşlerini almak için yapılandırılmamış görüşme yapılmıştır. Sorular önceden hazırlanmamış görüşme sonuçları not alınmıştır.

\section{Uygulama Süreci}

Deney grubunda oyun temelli oyunlaştırma yöntemi uygulanmış ve bu kapsamda bazı oyunlar yorumları ile birlikte verilmektedir.

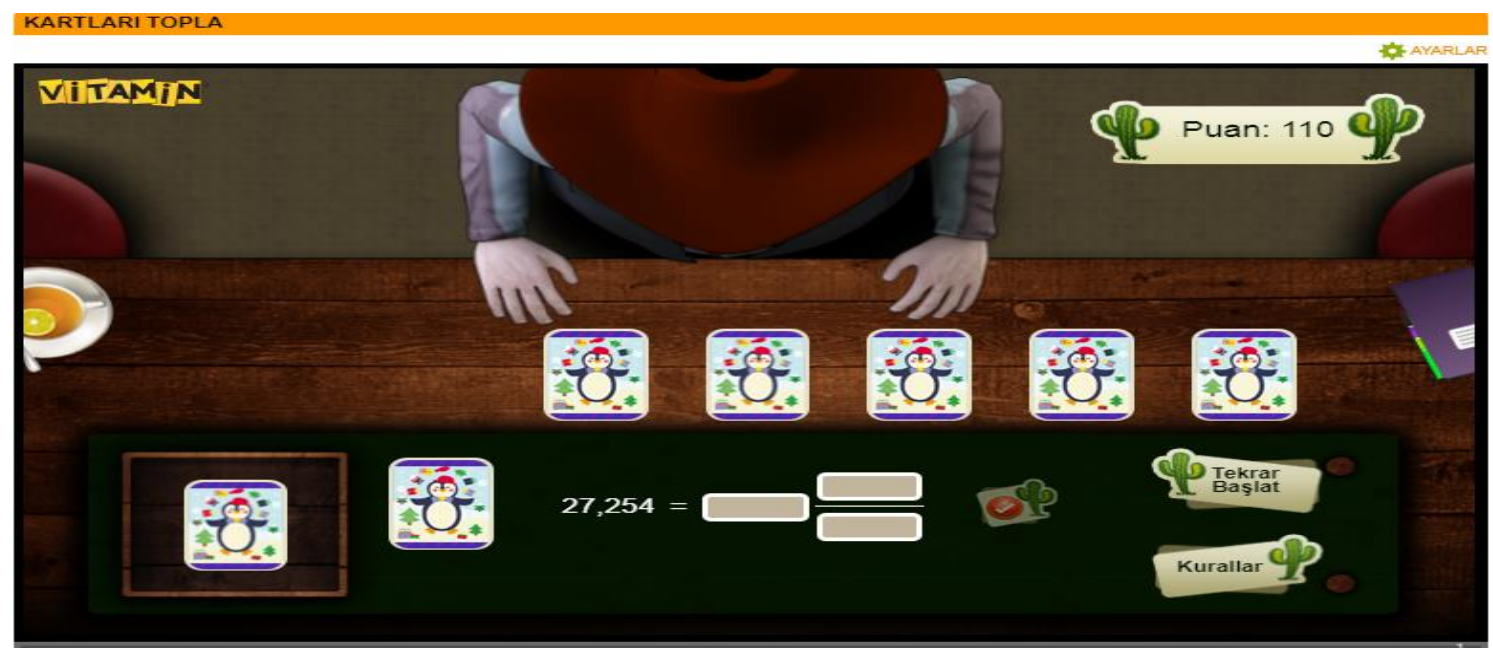

Şekil 1. Oyun Örneği

Oyunda ondalık gösterimi kesir gösterimine, kesir gösterimi ise ondalık gösterime çevirmek amaçlanmaktadır. Öğrenci seçtiği kartın altından çıkan kesir ya da ondalık gösterimi istenilen formata çevirerek cevabı doğru ise yaptığı işlemden puan almakta yanlış ise puan kaybetmektedir. Yine puan esasına dayanan bu oyunda öğrenciler bir rekabet ortamına girmekte en fazla puanı almak istemektedir.Amaç yine oyunda arkadaşlarını geçmek olsa da dolaylı yoldan konuya hakim olunmuştur.

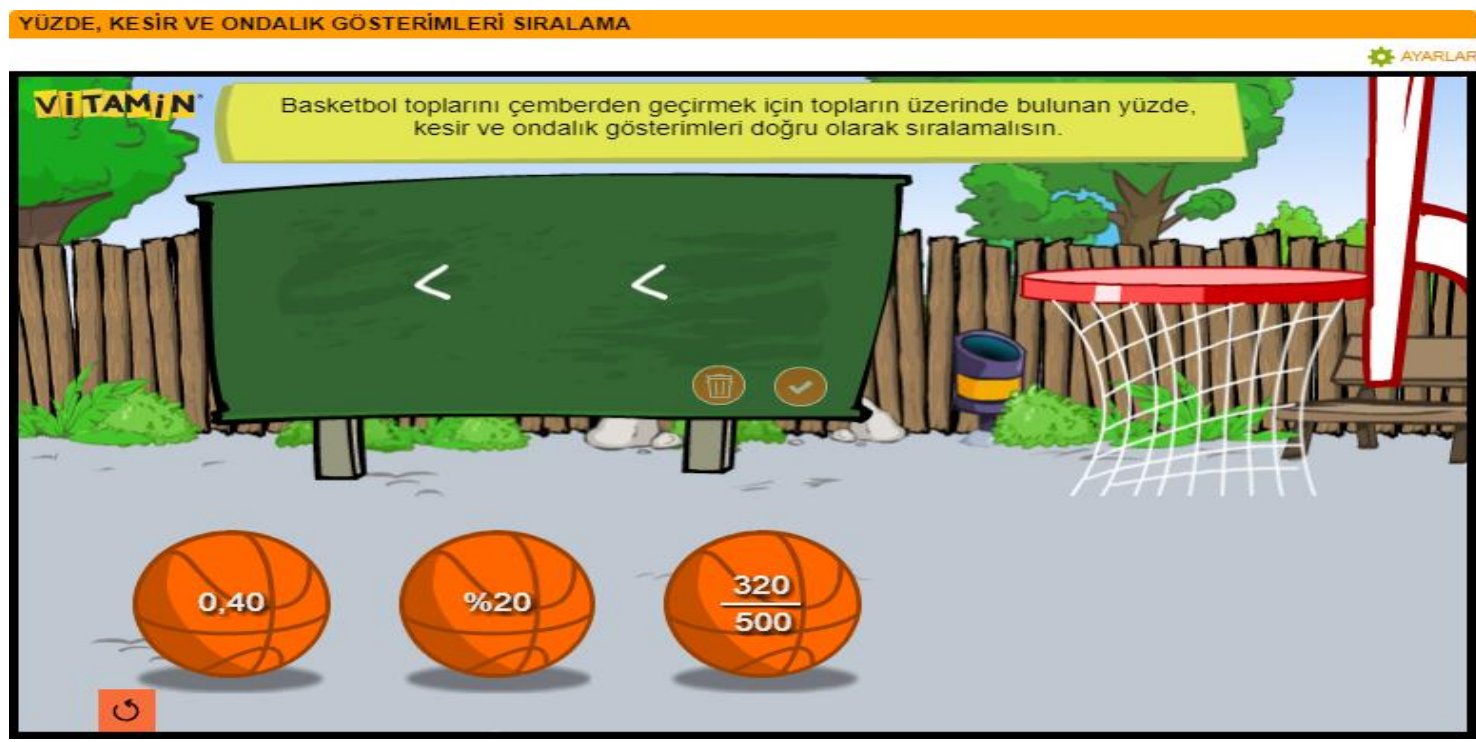




\section{Şekil 2. Oyun Örneği}

Bu oyun " Kesir, ondalık ve yüzdelik gösterimle belirtilen çoklukları karşılaştııı." kazanımına uygun olarak oynatılmıştır. Öğrencinin topları potaya atabilmesi için öncelikle tüm ifadeleri kesir gösterimde, ondalık gösterimde veya yüzdelik gösterimde göstermesi gerekmektedir. Tüm ifadeleri aynı gösterimle gösteren öğrenci topları potaya atmaya hak kazanmıştır. Öğrenciler bu oyunda aynı zamanda kesirlerde sadeleştirme ve genişletme de yaparak oynamaya başlamıştır. Klasik anlatımda "hadi bu kesirleri sıralayalım denildiğinde" çok istekli olmayan öğrenciler bile büyük bir istekle oyunu oynamıştır. Yanlış sıralama yapan öğrencinin topu potaya atamaması öğrenciler arasında bir heyecan oluşturmuştur. Başlangıçta belirli öğrenciler doğru yapsa da zamanla tüm öğrencilerin derse katılmaya çalışması ve doğru yapmaya başlaması öğrencileri derse motive ederken aynı zamanda öğrencilerin kazanımı tam olarak edinmelerine olanak sağlamaktadır.

\section{Verilerin Analizi}

Nicel veri analizi. Araştırmada deneysel olarak elde edilen veriler SPSS (The Statistical Packet for the Social Sciences) paket programı kullanılarak analiz edilmiştir.

Nitel veri analizi. Nitel araştırma yöntemleri, insanların kendi özelliklerinin farkında olma ve katkıda bulundukları toplumun derinliklerini araştırmak ve şekillendirmek için geliştirdikleri bilgileri üretme yollarından biridir. Nitel araştırma yöntemleri olayların altında yatan ya da görülmeyen durumların açığa çıkarılmasında önemli rol oynar. İnsanların hayata bakış açısını ortaya çıkarmak için önemlidir. Bizlere günlük hayatı tüm açıklığıyla göstermesi yönüyle oldukça önemlidir.

$\mathrm{Bu}$ çalışmada nicel araştırma desenlerinden deneysel ve ilişkisel araştırmaları nitel çalışmalar ile desteklemek için gömülü desen kullanılmıştır. Gömülü desen çalışmalarında genellikle gözlem notları ve görüşmeler kullanılmaktadır. Bunun yapılmasının amacı elde edilen nitel ve nicel verilerin birbirini desteklemesi ve bunun sonucu olarak daha kapsamlı ve güvenli bilgilere ulaşılmasıdır. Ulaşılan veriler bir araya toplanarak araştııılan durum zenginleştirilmiş ve durum hakkında derinlemesine bilgi edinilmiştir. Nitel araştırmaların verileri toplanırken ise "triangülasyon" olarak adlandırılan ve birden çok veri elde etme yöntem ve tekniğin kullanıldığı bir yaklaşım benimsenmektedir.

$\mathrm{Bu}$ araştırmada verileri toplamak için araç olarak; açık uçlu sorular, yapılandırılmamış görüşmeler kullanılmıştır. Uygulama sırasında olağan dışı bir şeyle karşılaşıldığında öğrencilere açık uçlu sorular yöneltilmiş̧tir. 14 haftalık uygulama sonrasında deney grubunda bulunan öğrenciler arasından gönüllü olan öğrenciler ile yapılandırılmamış görüşmeler yapılmıştır. Yapılan görüşmeler not edilmiştir.

Uygulama süresince yapılandırılmamış görüşmelerden elde edilen notlar nesnel olarak birleştirilmiş ve analiz etmek için düzenlenmiştir.

\section{Bulgular}

\section{Araştırmanın Birinci Problemine Ait Bulgular ve Yorum}

Araştırmanın birinci problemi "Deney grubu ve kontrol grubu öğrencilerinin ön test, son test başarı puanları arasında anlamı bir farklılık var mıdır? olarak belirlenmiştir. Veriler t-testi ile analiz edilmiştir. Araştırma öncesinde deney ve kontrol gruplarının birbirine başarı konusunda denk olup olmadığını belirlemek için deney grubunda ve kontrol grubunda bulunan öğrencilere matematik başarı testi ön test olarak uygulanmıştır. Deney ve kontrol grubundaki öğrencilerin puanları matematik başarı testi yönünden karşılaştırıldığında, puanlar arasında anlamlı bir ilişki olup olmadığı belirlemek için ilişkisiz örneklemler için t- testi (independent t-test) kullanılarak analiz edilmiş ve elde edilen bulgular Tablo 2'de gösterilmiş̧ir.

Tablo 2. Deney ve Kontrol Gurubunda Bulunan Öğrencilerin Ön Test Puanları İlişkisiz Örneklem t-testi Sonuçları

\begin{tabular}{lllllll}
\hline Gruplar & $\mathrm{n}$ & $\mathrm{B}$ & $\mathrm{S}$ & $\mathrm{sd}$ & $\mathrm{t}$ & $\mathrm{p}$ \\
\hline Deney & 28 & 10,1429 & 3,09975 & 48 &,- 483 &, 631
\end{tabular}




Kontrol $\quad 22 \quad 10,5909 \quad 3,44562$

Tablo 2 incelendiğinde, deney grubundaki öğrencilere uygulanan ön test ortalamasının $B=10,14$ olduğu, kontrol grubunda bulunan öğrencilere uygulanan ön test ortalamasının ise $B=10,59$ olduğu sonucuna ulaşılmıştır. Tablo incelendiğinde kontrol grubunda bulunan öğrencilerin ön test başarı puanlarının ortalaması deney grubunda bulunan öğrencilerin ön test başarı puanlarına göre fazla olsa da grupların uygulama öncesinde matematik dersi başarı ortalaması açısından aralarında anlamlı bir farklılığın olmadığı görülmüştür $(\mathrm{t}=-0,483, \mathrm{p}>0.05)$.

Araştırmada uygulanan iki farklı öğretim yönteminin öğrencilerin matematik başarısı üzerine etkisini tespit etmek için deney grubunda ve kontrol grubunda bulunan öğrencilerin ön test ve son test başarı puanları arasında anlamlı bir farklılığın olup olmadığını belirlemek için ilişkili örneklemler t- testi (Paired Samples t- test) kullanılmıştır. Kontrol grubunda bulunan öğrencilere deneysel işlem öncesinde uygulanan ön test başarı puanı ile son test başarı puanı arasındaki ilişki Tablo 3'de gösterilmiştir.

Tablo 3. Kontrol Grubunda Bulunan Öğrencilerin Ön Test ve Son Test Başarı Puanları İlişkili Örneklem t-testi Analizi Sonuçları

\begin{tabular}{lllllll}
\hline Testler & $\mathrm{n}$ & $\mathrm{B}$ & $\mathrm{S}$ & $\mathrm{sd}$ & $\mathrm{t}$ & $\mathrm{p}$ \\
\hline Ön test & 22 & 10,5909 & 3,44562 & 21 & 14,417 &, 000 \\
Son Test & 22 & 13,2727 & 3,97830 & & & \\
\hline
\end{tabular}

Tablo 3 incelendiğinde kontrol grubundaki öğrencilerin ön test başarı puan ortalamalarının $B=10,59$ olduğu, 14 haftalık uygulama sonrasında elde edilen son test başarı puanlarına göre ortalamalarının $B=13,27$ olduğu sonucuna ulaşıldığı görülmektedir. Öğrencilerin ön test ve son test başarı puanları arasındaki bu farkın istatistiksel olarak anlamlı bir fark olduğu görülmüştür $(\mathrm{t}=14,417, \mathrm{p}<0.05)$. Bu sonuca bakılarak, geleneksel öğretim yöntemleri ile yapılan matematik öğretiminin öğrencilerin öğrenmesine pozitif yönde olumlu etki yaptığ söylenebilir.

Deney grubundaki ön test başarı puanları ile son test başarı puanları arasında ilişki olup olmadığını belirlemek amacı ile ilişkili örneklemler t-test (Paired Samples t- test) kullanılmıştır. Analiz sonuçları Tablo 4 'te gösterilmiştir.

Tablo 4. Deney Grubunda Bulunan Öğrencilerin Ön Test ve Son Test Başarı Puanları İlişkili Örneklemler t-testi Analizi Sonuçları

\begin{tabular}{lllllll}
\hline Testler & $\mathrm{n}$ & $\mathrm{B}$ & $\mathrm{S}$ & $\mathrm{sd}$ & $\mathrm{t}$ & $\mathrm{p}$ \\
\hline Ön test & 28 & 10,1429 & 3,09975 & 27 & $-6,850$ &, 000 \\
Son Test & 28 & 13,3929 & 4,47494 & & & \\
\hline
\end{tabular}

Tablo 4 incelendiğinde deney grubunda bulunan öğrencilerin ön test puan ortalamalarının $B=10,14$ olduğu, 14 haftalık uygulama sonucunda elde edilen son test başarı puanlarına göre ortalamalarının $B=13,39$ olduğu sonucuna ulaşılmıştır. Deney grubunda bulunan öğrencilerin ön test başarı puanları ile son test başarı puanları arasında istatistiksel olarak son test puanları yönüne anlamlı bir ilişki olduğu görülmüştür $(\mathrm{t}=-6.850, \mathrm{p}<0.05)$. Bu bulgu, oyunlaştırılmış oyun temelli öğretim yönteminin öğrencilerin öğrenmesine olumlu yönde etki yaptığını göstermektedir. 
14 haftalık uygulama sonunda iki farklı yöntemin uygulandığı, deney grubunda ve kontrol grubunda bulunan öğrencilerin son test başarı puanları arasında anlamlı bir farkın olup olmadığını belirleyebilmek amacı ile ilişkisiz örneklemler için t- testi (Independent t-test) kullanılmıştır. Analiz sonuçları Tablo 5'te gösterilmiştir.

Tablo 5. Deney Grubunda ve Kontrol Grubunda Bulunan Öğrencilerin Son Test Başarı Puanları İlişkisiz Örneklemler t-testi Analizi Sonuçları

\begin{tabular}{lllllll}
\hline Gruplar & $\mathrm{n}$ & $\mathrm{B}$ & $\mathrm{S}$ & $\mathrm{sd}$ & $\mathrm{t}$ & $\mathrm{p}$ \\
\hline Deney & 28 & 13,3929 & 4,47494 & 48 &, 099 &, 922 \\
Kontrol & 22 & 13,2727 & 3,97830 & & & \\
\hline
\end{tabular}

Tablo 5 incelendiğinde oyunlaştırılmış oyun temelli öğrenme ortamlarının kullanıldığı deney grubunda bulunan öğrencilerin son test başarı puan ortalamalarının $B=13,39$ olduğu, geleneksel öğretim yönteminin uygulandığı kontrol grubu öğrencilerinin son test başarı puan ortalamalarının $B=13,27$ olduğu sonucuna ulaşılmıştır. Elde edilen bulgular incelendiğinde deney grubundaki öğrencilerin son test başarı puanları ve kontrol grubundaki öğrencilerin son test başarı puanları arasında istatistiksel olarak anlamlı bir fark olmadığ görülmüştür ( $\mathrm{t}=0,099, \mathrm{p}>0.05)$.

\section{Araştırmanın İkinci Problemine Ait Bulgular ve Yorum}

Araştırmanın ikinci problemi "Deney grubu ve kontrol grubu öğrencilerinin ön test tutum ve son test tutum puanları arasında anlamlı bir fark var mıdır?” olarak belirlenmiştir. Veriler t-testi ile analiz edilmiştir. Araştırma öncesinde deney grubundaki öğrenciler ile kontrol grubundaki öğrencilerin tutum puanlarına göre birbirine denk olup olmadığını belirlemek için deney ve kontrol grubundaki öğrencilere matematik tutum testi ön test olarak uygulanmıştır. Deney ve kontrol grubunda bulunan öğrencilerin tutum testinden aldıkların puanlar arasında anlamlı bir ilişki olup olmadığını belirlemek amacı ile ilişkisiz örneklemler için t- testi (Independent t-test) kullanılmış ve ulaşılan sonuçlar Tablo 6'da gösterilmiştir.

Tablo 6. Deney Grubunda ve Kontrol Grubunda Bulunan Öğrencilerin Ön Test Tutum Puanları İlişkisiz Örneklemler t-testi Analizi Sonuçları

\begin{tabular}{lllllll}
\hline Grup & $\mathrm{n}$ & $\mathrm{B}$ & $\mathrm{S}$ & $\mathrm{sd}$ & $\mathrm{t}$ & $\mathrm{p}$ \\
\hline Deney & 28 & 2,9126 &, 21041 & 48 &, 074 &, 942 \\
Kontrol & 22 & 2,9079 &, 24019 & & & \\
\hline
\end{tabular}

Tablo 6 incelendiğinde deney grubundaki öğrencilerin ön test tutum puanlarının ortalamasının $B=2,91$ olduğu, kontrol grubundaki öğrencilerin ön test tutum puanlarının ortalamasının $B=2,90$ olduğu sonucuna ulaşılmıştır. Ulaşılan sonuçlar incelendiğinde deney grubundaki öğrencilerin ön test tutum puanlarının kontrol grubunda bulunan öğrencilerin ön test tutum puanlarından yüksek olmasına rağmen aralarındaki bu farkın istatistiksel olarak anlamlı bir fark olmadığı görülmüştür $(\mathrm{t}=0,074, \mathrm{p}>0.05)$.

Kontrol grubunda uygulanan yöntem ile süreci tamamlayan öğrencilerin ön test tutum puanları ile 14 haftalık uygulama sonunda elde edilen son test tutum puanları arasında anlamlı bir ilişki olup olmadığını belirlemek amacı ile ilişkili örneklemler için t-testi (Paried Samples t-test) kullanılmıştır. Kontrol grubundaki öğrencilerin ön test tutum ve son test tutum puanları Tablo 7'de gösterilmiştir.

Tablo 7. Kontrol Grubunda Bulunan Öğrencilerin Ön Test ve Son Test Tutum Puanları İlişkili Örneklemler t-testi Analizi Sonuçları 


\begin{tabular}{|c|c|c|c|c|c|c|}
\hline Test & $\mathrm{n}$ & B & $\mathrm{S}$ & sd & $\mathrm{t}$ & $\mathrm{p}$ \\
\hline Ön Test & 22 & 2,9079 & ,24019 & 42 & $-1,002$ & ,322 \\
\hline Son Test & 22 & 2,9928 & ,31685 & & & \\
\hline
\end{tabular}

Tablo 7 incelendiğinde kontrol grubundaki öğrencilere ait ön test tutum puanlarının ortalamasının $B=2,90$ olduğu, son test tutum puanları ortalamasının ise $B=2,99$ olduğu sonucuna ulaşılmıştır. Elde edilen bulgularda kontrol grubunun son test tutum puanları ön test tutum puanlarından fazla olmasına rağmen aralarındaki farkın istatistiksel olarak anlamlı olmadığ görülmektedir $(\mathrm{t}=-1,002, \mathrm{p}>0.05)$.

Deney grubundaki öğrencilerin ön test tutum puanları ile 14 haftalık uygulama sonrasında elde edilen son test tutum puanları arasında istatistiksel olarak anlamlı bir ilişki olup olmadığını belirlemek amacı ile ilişkili örneklemler için t- testi (Paried Samples t-test) kullanılmıştır. Deney grubunda bulunan öğrencilerin ön test ve son test tutum puanlarını içeren t-testi analizi sonuçları Tablo 8'de gösterilmiştir.

Tablo 8. Deney Grubunda Bulunan Öğrencilerin Ön Test ve Son Test Tutum Puanları İlişkili Örneklemler t-testi Analizi Sonuçları

\begin{tabular}{lllllll}
\hline Test & $\mathrm{n}$ & $\mathrm{B}$ & $\mathrm{s}$ & $\mathrm{sd}$ & $\mathrm{t}$ & $\mathrm{p}$ \\
\hline Ön Test & 28 & 2,9126 &, 21041 & 54 & $-2,503$ &, 015 \\
Son Test & 28 & 3,0752 &, 27176 & & & \\
\hline
\end{tabular}

Tablo 8 incelendiğinde deney grubundaki öğrencilere ait ön test tutum puanlarının ortalamasının $B=2,91$ olduğu, son test tutum puanlarının ise $B=3,07$ olduğu sonucuna varılmıştır. Ulaşılan sonuçlar incelendiğinde deney grubunda bulunan öğrencilerin son test tutum puanlarının ortalamaları ön test tutum puanlarının ortalamalarından fazla ve aralarındaki farkın istatistiksel olarak son test yönünde anlamlı olduğu görülmektedir $(\mathrm{t}=-2,503, \mathrm{p}<0.05)$.

14 haftalık uygulama sonlandığında birbirinden farklı öğretim yöntemlerinin uygulandığı, deney grubu ve kontrol grubu öğrencilerinin son test tutum puanları arasında anlamlı bir farklılığın olup olmadığını belirlemek amacı ile ilişkisiz örneklemler için t- testi (Independent t-test) kullanılmıştır. Ulaşılan veriler Tablo 9'da gösterilmiştir.

Tablo 9. Deney Grubunda ve Kontrol Grubunda Bulunan Öğrencilerin Son Test Tutum Puanları İlişskisiz Örneklemler t-testi Analizi Sonuçları

\begin{tabular}{lllllll}
\hline Grup & $\mathrm{n}$ & $\mathrm{B}$ & $\mathrm{s}$ & $\mathrm{sd}$ & $\mathrm{t}$ & $\mathrm{p}$ \\
\hline Deney & 28 & 3,0752 &, 27176 & 48 &, 989 &, 328 \\
Kontrol & 22 & 2,9928 &, 31685 & & & \\
\hline
\end{tabular}

Tablo 9 incelendiğinde deney grubundaki öğrencilerin tutum puanları ortalamasının $B=3,07$ olduğu, kontrol grubundaki öğrencilerin ortalamasının $B=2,99$ olduğu sonucuna varılmıştır. Ulaşılan sonuçlar incelendiğinde deney grubunda bulunan öğrencilerin son test tutum puanları kontrol grubunda bulunan öğrencilerin son test 
tutum puanlarından fazla olsa da bu farkın istatistiksel olarak anlamlı bir fark olmadığ görülmüştür $(\mathrm{t}=0,989$, $\mathrm{p}>0,05)$.

\section{Araştırmanın Üçüncü Problemine Ait Bulgular ve Yorum}

Araştırmanın üçüncü problemi "Deney grubu ve kontrol grubu öğrencilerinin matematik başarı testi puanları arasında cinsiyete göre anlamlı bir farklılık var mıdır?” olarak belirlenmiştir. Veriler ilişkisiz örneklemler için Mann Whitney U-testi (MannWhitney U-testi Independent Samples) ile analiz edilmiştir.

Araştırma öncesinde deney grubundaki öğrenciler ile kontrol grubundaki öğrencilerin birbirlerine denk olduğunu belirleyebilmek için matematik başarı testi ön test olarak uygulanmıştır. Deney grubunda bulunan öğrenciler ile kontrol grubunda bulunan öğrencilerin cinsiyete göre ön testten elde ettikleri puanların arasında anlamlı bir farklılığın olup olmadığını belirlemek için Mann Whitney U-testi (Mann Whitney U-testi Independent Samples) kullanılmıştır. Deney grubu öğrencilerinin cinsiyete göre ön test başarı puanları arasındaki ilişki Tablo 10'da gösterilmiştir.

Tablo 10. Deney Gurubunda Bulunan Öğrencilerin Cinsiyete Göre Ön Test Puanları Mann Whitney U-testi testi Sonuçları

\begin{tabular}{lccccc}
\hline Cinsiyet & $\mathrm{n}$ & Sira Ortalamas1 & Sira Toplamı & $\mathrm{U}$ & $\mathrm{p}$ \\
\hline K1z & 12 & 16,08 & 193,00 & 77 &, 370 \\
Erkek & 16 & 13,31 & 213,00 & \\
\hline
\end{tabular}

Tablo 10 incelendiğinde deney grubundaki kız öğrencilerin ön test başarı sıra ortalamalarının $B=16,08$ olduğu, erkek öğrencilerin ön test başarı sıra ortalamalarının ise $B=13,31$ olduğu sonucuna ulaşılmıştır. Ulaşılan sonuçlar yorumlandığında deney grubunda bulunan kız öğrencilerin ön test başarı puanının erkek öğrencilerin ön test başarı puanından fazla olmasına rağmen aralarındaki farkın istatistiksel olarak anlamlı olmadığı görülmektedir ( $U=77$, $\mathrm{p}>0.05)$.

Araştırmada deney grubunda bulunan öğrencilerin cinsiyete göre son test başarı puanları arasındaki anlamlı bir ilişki olup olmadığını belirlemek için Mann Whitney U- testi (Mann Whitney U-testi Independent Samples) kullanılmıştır. Deney grubu öğrencilerinin cinsiyete göre son test başarı puanları arasındaki ilişki Tablo 11 'de gösterilmiştir.

Tablo 11. Deney Gurubunda Bulunan Öğrencilerin Cinsiyete Göre Son Test Puanları İlişkisiz Örneklem Mann Whitney U-testi testi Sonuçları

\begin{tabular}{lccccc}
\hline Cinsiyet & $\mathrm{n}$ & Sira ortalamasi & Sira toplamı & $\mathrm{U}$ & $\mathrm{p}$ \\
\hline $\mathrm{K} 1 \mathrm{z}$ & 12 & 15,54 & 186,50 & 83,50 &, 558 \\
Erkek & 16 & 13,72 & 219,50 & \\
\hline
\end{tabular}

Tablo 11 incelendiğinde deney grubundaki erkek öğrencilerin son test başarı sıra ortalamalarının $B=13,72$ olduğu, kız öğrencilerin son test başarı sıra ortalamalarının ise $B=15,54$ olduğu sonucuna varılmıştır. Ulaşılan sonuçlar yorumlandığında 14 haftalık uygulama sonrasında deney grubunda bulunan kız öğrencilerin son test başarı puanları erkek öğrencilerin son test başarı puanlarından fazla olmasına rağmen aralarındaki farkın istatistiksel olarak anlamlı bir fark olmadığı görülmektedir $(U=83,50, p>0.05)$.

Uygulama öncesinde MEB yapılandırmacı öğrenme ortamlarında öğrenim gören kontrol grubu öğrencilerine, araştırmacının hazırladığı başarı testi ön test olarak uygulanmıştır. Veriler Mann Whitney U-testi (Mann Whitney 288 
U-testi Independent Samples) kullanılarak analiz edilmiştir. Kontrol grubu öğrencilerinin cinsiyete göre ön test başarı puanları arasındaki ilişki Tablo 12'de gösterilmiştir.

Tablo 12. Kontrol Gurubunda Bulunan Öğrencilerin Cinsiyete Göre Ön Test Puanları Mann Whitney U-testi testi Sonuçları

\begin{tabular}{lccccc}
\hline Cinsiyet & $\mathrm{n}$ & Sira ortalamas & Sira toplami & $\mathrm{U}$ & $\mathrm{p}$ \\
\hline $\mathrm{K} 1 \mathrm{z}$ & 10 & 11,00 & 110,00 & 55 &, 736 \\
Erkek & 12 & 11,92 & 143,00 & \\
\hline
\end{tabular}

Tablo 12 incelendiğinde kontrol grubundaki erkek öğrencilerin ön test başarı sıra ortalamalarının $B=11,92$ olduğu, kız öğrencilerin ön test başarı sıra ortalamalarının ise $B=11,00$ olduğu sonucuna ulaşılmıştır. Tablo 12 'ye göre sonuçlar yorumlandığında 14 haftalık uygulama sonrasında deney grubunda bulunan erkek öğrencilerin deney grubundaki kız öğrencilere göre ön test başarı puanlarının daha fazla olmasına rağmen farkın istatistiksel olarak anlamlı olmadığı görülmektedir $(U=55, \mathrm{p}>0.05)$.

MEB yapılandırmacı sınıf ortamlarında derslerini sürdüren kontrol grubu öğrencilerine, uygulama öncesinde ön test olarak uygulanan başarı testi uygulamadan sonra son test olarak uygulanmıştır. Veriler Mann Whitney Utesti (Mann Whitney U-testi Independent Samples) kullanılarak analiz edilmiştir. Kontrol grubu öğrencilerinin cinsiyete göre son test başarı puanları arasındaki ilişki Tablo 13'de gösterilmiştir.

Tablo 1. Kontrol Gurubunda Bulunan Öğrencilerin Cinsiyete Göre Son Test Puanları Mann Whitney U-testi testi Sonuçları

\begin{tabular}{llllll}
\hline Cinsiyet & $\mathrm{n}$ & $\begin{array}{l}\text { Sira } \\
\text { ortalamas }\end{array}$ & Sira toplamı & $\mathrm{U}$ & $\mathrm{p}$ \\
\hline K1z & 10 & 11,15 & 111,50 & 56,5 &, 815 \\
Erkek & 12 & 11,79 & 141,50 & & \\
\hline
\end{tabular}

Tablo 13 incelendiğinde kontrol grubundaki erkek öğrencilerin son test başarı sıra ortalamalarının $B=11,79$ olduğu, kız öğrencilerin son test başarı sıra ortalamalarının ise $B=11,15$ olduğu görülmektedir. Ulaşılan sonuçlar yorumlandığında 14 haftalık uygulama sonrasında kontrol grubunda bulunan erkek öğrencilerin son test başarı puanlarının kız öğrencilerin başarı puanlarından daha yüksek olduğu fakat aralarındaki farkın istatistiksel olarak anlamlı olmadığı görülmüştür. ( $U=56,5, \mathrm{p}>0.05)$.

\section{Araştırmanın Dördüncü Problemine Ait Bulgular ve Yorum}

Araştırmanın dördüncü problemi "Deney grubunda ve kontrol grubunda bulunan öğrencilerin ön test ve son test tutum puanları arasında cinsiyete göre anlamlı bir farklılık var mıdır?” olarak belirlenmiştir. Veriler t ilişkisiz örneklemler için Mann Whitney U-testi (Mann Whitney U-testi Independent Samples) ile analiz edilmiştir. 
Deney grubundaki öğrencilerin ön test tutum puanlarının cinsiyete göre anlamlı bir fark olup olmadığını belirleyebilmek için yapılan Mann Whitney U-testi (Mann Whitney Utesti Independent Samples) sonuçları Tablo 14'te gösterilmiştir.

Tablo 2. Deney Gurubunda Bulunan Öğrencilerin Cinsiyete Göre Ön Test Tutum Puanlarının Mann Whitney Utesti Sonuçları

\begin{tabular}{lccccc}
\hline Cinsiyet & $\mathrm{n}$ & Sira ortalamasi & Sira toplami & $\mathrm{U}$ & $\mathrm{p}$ \\
\hline $\mathrm{K} 1 \mathrm{z}$ & 12 & 15,79 & 189,50 & 80 &, 471 \\
Erkek & 16 & 13,53 & 216,50 & & \\
\hline
\end{tabular}

Tablo 14 incelendiğinde deney grubundaki erkek öğrencilerin ön test tutum puanları sıra ortalamalarının $B=$ 13,53 olduğu, kız öğrencilerin ön test tutum puanları sıra ortalamalarının ise $B=15,79$ olduğu görülmektedir. Ulaşılan sonuçlar yorumlandığında deney grubunda bulunan kız öğrencilerin ön test tutum puanlarının deney grubunda bulunan erkek öğrencilerin tutum puanından daha fazla olduğu fakat aralarında istatistiksel olarak anlamlı bir fark olmadığ görülmektedir $(U=80,00, \mathrm{p}>0.05)$.

Deney grubunda bulunan öğrencilerin son test tutum puanları arasında cinsiyete göre anlamlı fark olup olmadığını tespit edebilmek için yapılan Mann Whitney U-testi (Mann Whitney Utesti Independent Samples) sonuçları Tablo 15 'te gösterilmiştir.

Tablo 3. Deney Gurubunda Bulunan Öğrencilerin Cinsiyete Göre Son Test Tutum Puanlarının Mann Whitney Utesti Sonuçları

\begin{tabular}{lccccc}
\hline Cinsiyet & $\mathrm{n}$ & Sira ortalamasi & Sira toplamı & $\mathrm{U}$ & $\mathrm{p}$ \\
\hline K1z & 12 & 13,08 & 157 & 79 &, 430 \\
Erkek & 16 & 15,26 & 249 & & \\
\hline
\end{tabular}

Tablo 15 incelendiğinde deney grubundaki erkek öğrencilerin son test tutum puanları sıra ortalamalarının $X=15,26$ olduğu, k1z öğrencilerin son test tutum puanları sira ortalamalarının ise $X=13,08$ olduğu gözlemlenmektedir. Elde edilen bulgular yorumlandığında deney grubunda bulunan erkek öğrencilerin son test tutum puanlarının deney grubunda bulunan kız öğrencilerin tutum puanlarından daha fazla olduğu fakat aralarında istatistiksel olarak anlamlı bir farklılığın olmadığı görülmektedir ( $U=79,00, \mathrm{p}>0.05)$.

Araştırmada kontrol grubunda bulunan öğrencilerin cinsiyete göre ön test tutum puanları da incelenmiştir. Veriler Mann Whitney U-testi (Mann Whitney U-testi Independent Samples) Tablo 16 ' da gösterilmiştir.

Tablo 4. Kontrol Gurubunda Bulunan Öğrencilerin Cinsiyete Göre Ön Test Tutum Mann Whitney U-testi Sonuçları

\begin{tabular}{|c|c|c|c|c|c|}
\hline Cinsiyet & $\mathrm{n}$ & Sira ortalaması & Sira toplamı & $\mathrm{U}$ & $\mathrm{p}$ \\
\hline
\end{tabular}




\begin{tabular}{lccccc}
\hline Kiz & 10 & 8,40 & 84,00 & 29 &, 040 \\
Erkek & 12 & 14,08 & 169,00 & \\
\hline
\end{tabular}

Tablo 16 incelendiğinde kontrol grubundaki erkek öğrencilerin ön test tutum puanları sıra ortalamalarının $B=14,08$ olduğu, kız öğrencilerin ön test tutum puanları sıra ortalamalarının ise $B=8,40$ olduğu sonucuna ulaşıldığı görülmektedir. Uygulama öncesinde MEB yapılandırmacı öğrenme ortamlarında öğrenim gören kontrol grubu öğrencilerine, Duatepe ve Kaygısız (1999)'ın hazırladığı tutum testi ön test olarak uygulanmıştır. Elde edilen veriler ilişkisiz örneklemler için Mann Whitney U-testi (Mann Whitney U-testi Independent Samples) ile analiz edilmiştir. Elde edilen bulgular incelendiğinde ön test tutum puanları arasında istatistiksel olarak erkek öğrenciler yönünde anlamlı bir farklılık olduğu gözlemlenmiştir $(U=29,00, p<0.05)$.

Araştırmada kontrol grubunda bulunan öğrencilerin cinsiyet açısından son test tutum puanları da incelenmiştir. Veriler ilişkisiz örneklemler için Mann Whitney U-testi (Mann Whitney U-testi Independent Samples) Tablo 17' de gösterilmiştir.

Tablo 5. Kontrol Gurubunda Bulunan Öğrencilerin Cinsiyete Göre Son Test Tutum Mann Whitney U-testi Sonuçları

\begin{tabular}{lccccc}
\hline Cinsiyet & $\mathrm{n}$ & Sira ortalamas & Sira toplamı & $\mathrm{U}$ & $\mathrm{p}$ \\
\hline $\mathrm{K} 1 \mathrm{z}$ & 10 & 9,25 & 92,50 & 37 &, 137 \\
Erkek & 12 & 13,38 & 16,50 & & \\
\hline
\end{tabular}

Tablo 17 incelendiğinde kontrol grubunda bulunan erkek öğrencilerin son test tutum puanları sıra ortalamaları $X=13,38$ iken, kız öğrencilerin son test tutum puanları sıra ortalamaları $X=9,25$ olduğu gözlemlenmektedir. Kontrol grubunda bulunan öğrenciler ile MEB'in hazırlamış olduğu yapılandırmacı yaklaşıma dayalı müfredat kapsamında ders kitabında yer alan etkinliklerle derslere devam etmiştir. Araştırma öncesinde ön test olarak uygulanan tutum testi, araştırma sonunda son test olarak uygulanmıştır. Elde edilen veriler ilişkisiz örneklemler için Mann Whitney U-testi (Mann Whitney U-testi Independent Samples) analiz edilmiştir. $\mathrm{Bu}$ bulgular doğrultusunda kontrol grubunda bulunan erkek öğrencilerin ortalamaları kız öğrencilerinkinden fazladır fakat aralarında istatistiksel olarak anlamlı bir farklılık gözlemlenmemiştir ( $U=37,00, p>0.05)$.

\section{Araştırmanın Beşinci Problemine Ait Bulgular ve Yorum}

Araştırmanının beşinci problemi “Oyunlaştırma yöntemi kullanılarak yapılan öğretim hakkında öğrenci görüşleri nelerdir?", olarak belirlenmiştir. Bu araştırma probleminin bulguları öğrenciler ile yapılan yapılandırılmamış görüşmelerden ve uygulama sırasında araştırmacının aldı̆̆ı notlardan oluşmaktadır. Öğrencilerden elde edilen cevaplarda, öğrencilerin kimlik bilgilerini gizli tutmak amacıyla öğrencilere farklı isimler verilmiştir.

Deney grubundaki öğrencilere "Uygulama içerisinde diğer arkadaşlarınla etkileşim oldu mu olduysa nasıl oldu? ” sorusu sorulmuştur. Öğrencilerin geneli kendinden önceki arkadaşlarının oyunlarını izleyip onlardan daha iyi yapmak için tüm dikkatlerini oyuna verdiklerini söylemişlerdir. Ayrıca öğrencilerin birçoğu oyunu bitirebilmek için arkadaşları ile yardımlaştığını dile getirmiştir.

Öğrencilere "Ders içerisinde rekabet hissine kapıldın $m \imath$ ?" sorusu sorulmuştur. Öğrencilerin vermiş oldukları cevap incelendiğinde, öğrencilerin arkadaşlarından daha fazla puan kazanabilmek için çabaladığını oyunu oynayan tüm arkadaşlarının oyunlarını takip ederek onların aldıkları puanlardan daha fazla puan alarak onları geçmeye çalıştıklarını belirtmişlerdir. 
Öğrencilere "Okuldaki normalde işlenen dersler ile yapılan bu uygulamalar arasında benzerlikler var mıydı?" ve "Neler benziyordu?" soruları yöneltilmiştir. Öğrenciler uygulamalarla normalde işlenen derslerden farklı olarak çok eğlendiklerini, öğrenme kaygısı gütmediklerini dile getirmişlerdir. Başka uygulamalarla olan ortak yanı her iki uygulama sonunda da soruları çözebilir hale gelmiş olmaları olduğunu dile getirmişlerdir.

Son olarak öğrencilere "Okuldaki tüm derslerin böyle olmasını ister misin?" sorusu sorulmuştur. Öğrencilerin geneli tüm derslerin bu şekilde işlenmesini istediklerini dile getirmiştir. Böylece derslerden sıkılmayıp keyif aldıklarını, arkadaşları ile ilişkilerinin daha iyi olduğunu, derslerde sürekli oturmaktan ders dinlemekten sıkıldıklarını ancak bu şekilde derste daha aktif olduklarını ifade etmişlerdir.

\section{Tartışma ve Sonuç}

\section{Araştırmanın Birinci Problemine İlişkin Tartışma ve Sonuçlar}

Araştırmanın birinci problemi "Deney grubu ve kontrol grubu öğrencilerinin ön test ve son test başarı puanları arasında anlamı bir farklılık var mıdır?" olarak belirlenmiştir.

Araştırma öncesinde elde edilen bulgulara göre, aktif öğrenme yöntemlerinden bir tanesi olan oyunlaştırılmış oyun temelli öğrenme yönteminin uygulandığı deney grubu ile MEB yapılandırılmış öğrenme yönteminin uygulandığı kontrol grubu öğrencilerinin ön test başarı puanları arasında istatistiksel olarak anlamlı bir farklılık bulunamamış̧ır. Ulaşılan bu sonuca bakıldığında, araştırma öncesinde deney ve kontrol grubunda bulunan öğrencilerin başarı düzeylerinin ve hazır bulunuşluklarının birbirine denk olduğu söylenebilir. Uygulama sonucunda elde edilen bulgulara göre, aktif ögrenme yöntemlerinden bir tanesi olan oyunlaştırılmış oyun temelli öğrenme yönteminin uygulandığı deney grubu ile MEB yapılandırılmış öğrenme yönteminin uygulandığı kontrol grubu öğrencilerinin son test başarı puanları arasında istatistiksel olarak anlamlı bir farklılık bulunamamıştır.

Araştırma sonucunda elde edilen sonuçlara göre oyun temelli öğrenme yöntemiyle yapılan öğretimin MEB yapılandırılmış öğretim yöntemi kadar başarılı olduğu gözlenmektedir. Araştırma sonucunda deney grubunda bulunan öğrenciler ile kontrol grubunda bulunan öğrencilerin başarı puanları arasında anlamlı bir farklılık bulunamamasının sebebi öğrencilerin oyun oynarken konuyu kavradıklarını göstermektedir.

Araştırma sonucuna bakıldığında oyunlaştırılmış oyun temelli öğrenme ortamlarında öğrenim gören öğrenciler ile MEB yapılandırılmış öğrenme ortamlarında öğrenim gören öğrencilerin başarı puanları arasında anlamlı bir farklılık çıkmasa da oyunlaştırılmış oyun temelli öğrenme ortamlarının öğrenme sürecine sağladığı faydalar göz ardı edilemez. Çalışma sonucunda ulaşılan bu sonuç literatürde oyunlaştırma yöntemi kullanılarak yapılan Polat (2014) ve Samur (2015) tarafından yapılan çalışmaların sonuçları ile paralellik göstermektedir.

Eldeki bilgiler ışığında hem oyunlaştırılmış oyun temelli öğrenme yöntemi ile hem de MEB yapılandırılmış öğretim yöntemi öğrencilerin matematik başarılarını olumlu yönde geliştirmesine rağmen istatistiksel olarak anlamlı bir fark elde edilememiştir.Oyun temelli öğrenme yöntemi öğrencilere yaparak yaşayarak öğrenme firsatı sunmaktadır (Aksoy, 2014). Öğrencilerin problem çözme becerilerini geliştirmektedir (Doğusoy ve İnal, 2006). Oyuncuların yapmış oldukları eylemlerde doğrudan dönüt sağlayarak öğrencileri doğruyu bulmaya yönlendirmektedir (Bayırtepe ve Tüzün, 2007). Oyun temelli öğrenme yöntemi ve MEB yapılandırılmış öğretim yönteminin avantaj ve dezavantajlarına bakıldığında, dijital bilgisayar oyunlarının derslerde kullanımının öğrenciler açısından olumlu olduğu görülmektedir.

\section{Araştırmanın İkinci Problemine İlişkin Tartışma ve Sonuçlar}

Araştırmanın ikinci problemi "Deney grubu ve kontrol grubu öğrencilerinin ön test ve son test tutum puanları arasında anlamlı bir farklılık var mıdır?" olarak belirlenmiştir.

Araştırma öncesinde elde edilen bulgulara göre, deney grubu ve kontrol grubu öğrencilerinin ön test tutum puanları arasında istatistiksel olarak anlamlı bir farklılık bulunamamıştır. Bu sonuç uygulama öncesinde deney grubundaki ve kontrol grubundaki öğrencilerin matematik dersine karşı olan tutumlarının birbirine denk olduğunu göstermektedir. Araştırma sonunda elde edilen bulgular incelendiğinde ise deney grubu öğrencilerinin ve kontrol grubu öğrencilerinin son test tutum puanları arasında yine anlamlı bir farklılık gözlenmemiştir.

Araştırma sonucunda elde edilen bulgular incelendiğinde oyunlaştırılmış oyun temelli öğrenme ortamlarında ve MEB yapılandırmacı öğrenme ortamlarında öğrenim gören öğrencilerin son test tutumlarının birbirine benzer olduğu gözlenmektedir. Bu durum, öğrencilerin derse karşı olan tutumlarının kolay kolay değişmeyeceğini, 
tutumların eskiden süre geldiğini ve uzun bir zaman aralığında değișeceğini bizlere göstermektedir. Öğrencilerin matematiğe olan tutumları geçmişten bu yana var olan bir algı olduğu için bunu 14 haftalık bir sürede tamamen değiştirmek fazla mümkün olmamıştır. Sonuçlar incelendiğinde yine deney grubunun tutum puanı kontrol grubundan fazla çıkmış fakat istatistiksel olarak bir farklılık oluşmamıştır. Ulaşılan sonuçlar incelendiğinde daha uzun bir zaman içerisinde eğitsel dijital oyunlar kullanılırsa öğrencilerin matematik dersine karşı tutumlarının arttırabileceği söylenebilir.

Öğrencilerin tutum puanları incelendiğinde kontrol grubu öğrencilerinin ön test tutum puanları ve son test tutum puanları arasında anlamlı bir farklılık gözlemlenmezken, deney grubunda bulunan öğrencilerin son test tutum puanları arasında anlamlı bir farklılık gözlemlendiği dikkat çekmektedir. Bu bulgudan deney grubunda uygulanan oyunlaştırılmış oyun temelli öğrenme yöntemlerinin öğrencilerin matematik dersine karşı tutumlarını olumlu yönde artırdığı söylenebilir. Bu sonuca hem uygulama esnasında yapılan gözlemler sonucunda hem de uygulama sonrasında yapılan görüşmeler sonucunda ulaşılmıştır. Öğrenciler eğlendikleri ve zevk aldıkları oyunlaştırılmış oyun temeli öğrenme ortamlarında derslerin işlenmesine devam etmek istemişlerdir. Ayrıca öğrencilere yöneltilen, "Hangi dersleri EBA oyunlarını kullanarak işlemek istersiniz?" sorusuna cevap olarak öğrenciler genellikle matematik dersinin oyunlaştırılmış oyun temelli öğrenme yöntemiyle işlenmesini istediklerini belirtmişlerdir. Öğrencilerin EBA oyunlarını genel olarak kullanmak istedikleri görülmüştür. Araştırma sonucunda deney grubunda bulunan öğrencilerin tutum puanlarının 14 haftada olumlu yönde arttığ gözlemlenmiştir. Öğrenciler derslerde aktif oldukları, eğlendikleri, zevk aldıkları için oyunlaştırılmış oyun temelli öğrenme ortamlarından oldukça keyif almışlarıdır. Bu sonuçlar, uygulamaya devam edildiğinde matematik dersine karşı olan tutumun olumlu yönde artarak devam edilebileceğini göstermektedir.

\section{Araştırmanın Üçüncü Problemine İlişkin Tartışma ve Sonuçlar}

Araştırmanın üçünücü problemi "Deney grubu ve kontrol grubu öğrencilerinin ön test ve son test başarı puanları arasında cinsiyete göre anlamlı bir farklılık var mıdır?” olarak belirlenmiştir.

Deney ve kontrol grubunda bulunan öğrencilere uygulanan ön test başarı ve son test başarı puanları arasında cinsiyete göre istatistiksel olarak anlamlı bir fark görülmemiştir . Elde edilen bu sonuç ile ilgili olarak literatürde yapılan çalışmaların sonuçları benzerlik göstermektedir (Annetta, vd., 2009; Bayırtepe \& Tüzün, 2007; Brom, vd., 2011; Clark, vd., 2011; Korkusuz,2012; Malta, 2010; Yağız, 2007). Bu sonuç araştırmada uygulanan öğretim yöntemlerinin öğrencilerin kız veya erkek olmalarının matematik dersine karşı başarı puanlarını etkilemediği sonucunu ortaya koymaktadır.

\section{Araştırmanın Dördüncü Problemine İlişkin Tartışma ve Sonuçlar}

Araştırmanın dördüncü problemi "Deney grubunda ve kontrol grubunda bulunan öğrencilerin ön test ve son test tutum puanları arasında cinsiyete göre anlamlı bir farklılık var mıdır?” olarak belirlenmiştir.

Deney ve kontrol grubunda bulunan öğrencilerde kontrol grubu son test, deney grubu ön test ve son testte uygulanan tutum testi puanları arasında cinsiyete göre anlamlı bir farklılığın olmadığı gözlemlenmiştir. Sadece kontrol grubu ön testte cinsiyete göre anlamlı bir farklılık gözlemlenmiştir. Ulaşılan sonuçların geneline bakıldığında erkek kız öğrencilerin matematik dersine karşı olan tutumları arasında istatistiksel olarak anlamlı bir fark olmadığı gözlemlenmektedir. Çalışma sonucunda ulaşılan bu sonuç literatürde oyunlaştırma yöntemi kullanılarak Şahin (2015) tarafından yapılan çalışmaların sonuçları ile paralellik göstermektedir.

Araştırmada dikkat çeken bir nokta da deney grubunda bulunan erkek öğrencilerin ön test tutum puanları kız öğrencilerden düşükken son test tutum puanlarında erkek öğrencilerin puanları kız öğrencilerinkinden yüksek çıkmıştır. Bunun sebebi bilgisayar oyunları erkek öğrencilerin dikkatini kız öğrencilere oranla daha fazla çekmiş olması olabilir. Genele bakıldığında erkek öğrenciler daha çok bilgisayar oyunları ile ilgilenmekte dijital ortamda olan her şey onların dikkatini çekebilmektedir. Bu sonuca öğrencilerle yapılan görüşmeler sayesinde varılmıştır. Yapılan görüşmelerde erkek öğrenciler bu oyunların kendi oynadıkları oyunlardan çok daha kolay olduğunu dile getirmişlerdir. Öğrenciler oyun oynarken çok keyif aldıklarını, eğlendiklerini dile getirdikleri için oyunun öğretim ortamında kullanılması öğrencilerin matematik dersine karşı olan tutumlarını olumlu yönde etkileyebilir. bunu öğretim ortamında uygulamak öğrenciler için çok daha iyi olacaktır. 


\section{Araştırmanın Beşinci Problemine İlişkin Tartışma ve Sonuçlar}

Araştırmanın beşinci problemi "Oyunlaştırılmış oyun temelli öğrenme yöntemi kullanılarak yapılan öğretim hakkında öğrenci görüşleri nelerdir?” olarak belirlenmiştir. Araştırma sonunda öğrencilerin uygulama sürecine ilişkin görüşleri yapılandırılmamış görüşmeler ile elde edilmiştir. Öğrencilerle yapılan bu görüşmelerde notlar alınmış öğrencilere yöneltilen soruların cevapları yorumlanmıştır.

Deney grubundaki öğrenciler ile yapılan görüşmelerde, oyun temelli öğrenme ortamının öğrenciler arasında yardımlaşmayı sağladığı sonucuna ulaşılmıştır. Takım halinde yarışan öğrenciler geride kalmamak için başarılı olan öğrenciler başarılı olamayan arkadaşlarına yardımcı olmuşlardır. Akran eğitimi de bu aşamada devreye girmiştir. Bu sayede öğrenciler arasında yeni güzel bağlar kurulmaya başlamıştır. Oyunda başarılı olamayan öğrencilere başarılı olan arkadaşları yardım ederek onun da öğrenmesine yardımcı olmuşlardır. Öğrenciler oyunlardan aldıkları zevki ve eğlenceyi dersten de aldıklarını ifade etmişlerdir. Matematik derslerinde normalde sıkıldıklarını ama dijital oyunlar kullanıldığında dersin eğlenilerek işlendiğini dile getirmiştir. Öğrenciler derste zamanın nasıl geçtiğini anlamadıklarını ifade etmişlerdir.

Kontrol grubunda yapılan görüşmelerde öğrencilere yöneltilen sorulara verdikleri cevaplarda genelde matematik derslerinde çok sıkıldıklarını belirtmişlerdir. Gerçekten somut işlemler dönemindeki öğrenciler için oldukça soyut olan matematik dersi öğrencilerin algısında sıkıcı ve tekdüze bir ders yerine oturmuştur. Bu şekilde yapılan oyunlar öğrencilerin matematik dersine karşı olan tutum ve ilgilerini olumlu yönde etkileyecektir.

Günümüzde EBA daki oyunlar dersler için kullanışlı ve belirlenen hedeflere ulaşmada öğretmenlere en büyük yardımcıdır. Öğrencilerin evlerinde kendilerinin de kullanabildikleri bu ă̆ sayesinde öğrenciler, tamamlamak istedikleri konuyu okuldaki ders saatleri dışında da çalışabilir hale gelmişlerdir. Öğrencilere oyun oynama, soru çözme, istedikleri bir konuyu dinleme imkânı sunan EBA bu olanakları ile öğrencilerin sıkça kullanabilecekleri bir ăg haline gelmiştir.

\section{Öneriler}

Literatürde yeni bir kavram olarak karşımıza çıkan oyunlaştırma kavramı ile ile farklı öğrenme alanlarında ve farklı sınıf düzeylerinde çalışmalar yapılabilir.Öğrenciyi derse motive etmek için kullanılan oyunlaştırma yöntemini eğitim ortamlarına entegre ederek MEB tarafından belirlenen hedef kazanımların gerçekleştirilmesi daha çekici ve cazip hale getirilebilir.EBA oyunları üzerine farklı sınıf düzeylerinde ve farklı ögrenme alanlarında çalışmalar yapılabilir. Araştırma süresinin 14 hafta olduğu göz önüne alındığında özellikle 5, 6, 7 ve 8' inci sınıfta bulunan öğrenciler ile yapılırsa daha doğru sonuçlar alınabilir.Sınırlılıklardan dolayı bu çalışma 50 öğrenci ile yürütülmüştür. Yapılacak başka çalışmalar çok daha fazla öğrenci ile yapıldığında önümüze daha net bir tablo çıkarabilir.Bu araştırma sosyo-ekonomik düzeyi düşük seviyede sayılabilecek iki okulda gerçekleştirilmiştir. Sosyo-ekonomik düzeyi farklı bölgelerde de benzer çalışmalar yapılabilir.Okullarda okutulan seçmeli matematik uygulamaları dersi içerisinde EBA oyunları sıç̧a kullanılabilir.MEB tarafından öğretmenlere oyunlaştırma ile ilgili hizmet içi eğitim imkânları sağlanarak öğretmenlerin bu konuda kendilerini geliştirmeleri sağlanabilir. Öğrenciler tarafından çok ta sevilmeyen matematik dersi bu şekilde yapılan etkinlikler sayesinde sevilir hale getirilebilir. Eğitim fakültelerinde dijital ortamda öğrencilerle yapılabilecek oyunlar ve etkinlikler üzerine yaptırılan çalışmalarla atanmadan öğretmen adayları bu uygulamaları benimsemiş hale getirilebilir.

\section{Teşekkür ve Bilgilendirme}

"Oyunlaştırma Yöntemiyle Öğrenmenin Öğrencilerin Matematik Dersi Başarılarına ve Derse Yönelik Tutumlarına Etkisi" adlı yüksek lisans tez çalışmasından üretilmiştir. Bu çalışma, Erciyes Üniversitesi Bilimsel Araştırma Projeleri Birimi tarafından SYL-2016-6993 kodlu proje ile desteklenmiştir. 


\section{References}

Airasian, P. W. \& Walsh, M. E. (1997). Cautions for classroom constructivists. Education Digest, 62 (8), $62-$ 69.

Akpınar, Y. (1999). Bilgisayar destekli ögretim ve uygulamalar [Computer-aided instruction and practises]. Ankara: Anı Publishing.

Aksoy, N. C. (2014). Dijital oyun tabanlı matematik öğretiminin ortaokul 6. sınıf ̈̈̆rencilerinin başarılarına, başarl güdüsü, öz-yeterlilik ve tutum özelliklerine etkisi [Effects of digital game-based mathematics teaching on 6th grades students' achievement, motivation, attiude and self-efficacy]. Unpublished Doctorate Dissertation, Gazi University, Ankara.

Aksu, M. (1985). Ortaöğretim Kurumlarında Matematik Öğretimi ve Sorunlarl [Mathematics Teaching and Problems in Secondary Education Institutions]. Ankara: T.E.D. Publishing Education Series No:3, Yorum-Basin Limited Company.

Altun, M. (2005). Ĕ̆itim fakülteleri ve ilköğretim öğretmenleri için: matematik öğretimi [Teaching Mathematics For Faculty of Education and Primary School Teachers]. İstanbul: Alfa Publishing .

Bağcı, H. \& Çoklar, A., N. (2014). Bilgisayar oyunları, eğitsel kullanımları ve tasarım yeterlilikleri açısından BÖTE öğretmen adaylarının değerlendirilmesi [The evaluation of CEIT teacher candidates in terms of computer games, educational use of computer games and game design qualifications]. Journal of Theoretical Educational Science. 7(2), 195-211.

Bakar, A., Tüzün, H. \& Çağıltay, K. (2008). Öğrencilerin eğitsel bilgisayar oyunlarını kullanımına ilişkin görüşleri: Sosyal bilgiler dersi örneği [Students’ opınıons of educatıonal computer game utılızatıon: a socıal studies course case]. Hacettepe University Education Faculty Journal, 35(35), 27-37.

Bayırtepe, E. \& Tüzün, H. (2007). Oyun-tabanlı öğrenme ortamlarının öğrencilerin bilgisayar dersindeki başarıları ve öz-yeterlik algıları üzerine etkileri [The effects of game-based learnıng environments on students' achievement and self-efficacy in a computer course]. Hacettepe University Education Faculty Journal, 33(33), 41-54.

Baykul,Y., (1997) . Illkögretimde Matematik Öğretimi [Mathematics Teaching in Primary Education]. Ankara: An1 Publishing

Brom, C., Preuss, M. \& Klement, D. (2011). Are educational computer micro-gamesengaging and effective for knowledge acquisition at high-schools? A quasiexperimentalstudy. Computers\& Education, 57, 1971-1988.

Bulut N. (1998). İnsan ve Matematik [Human and Mathematics]. İzmir: Delta Publishing.

Büyüköztürk, Ş., Kılıç-Çakmak E., Akgün Ö. E., Karadeniz Ş. \& Demirel, F.(2008). Bilimsel araştırma yöntemleri[ Scientific research methods](11. Edition). Ankara; Pegem Akademi.

Clarck, D. B., Nelson, B. C., Chang, H., Martinez-Garza, M., Slack, K. \& D’Angelo, C.M. (2011). Exploring Newtonian mechanics in a conceptually-integrated digital game: Comparison of learning and affective outcomes for students in Taiwanand the United States. Computers \& Education,57, 2178-2195.

Çağıltay, K., Çakıroğlu, J., Çağıltay, N. \& Çakıroğlu, E. (2001). Öğretimde bilgisayar kullanımına ilişkin öğretmen görüşler [Teachers' perspectıves about the use of computers in education. Hacettepe University Education Faculty Journal, 21(21), 19-48.

Çankaya, S. \& Karamete, A. (2008). Eğitsel bilgisayar oyunlarının öğrencilerin matematik dersine ve eğitsel bilgisayar oyunlarına yönelik tutumlarına etkisi [The Effects of Educational Computer Games on Students' Attitudes towards Mathematics Course and Educational Computer Games]. Mersin University Education Faculty Journal, 4(2), 115-127.

Çetin, E. (2013). Tanımlar ve temel kavramlar [Definitions and Basic Concepts]. Ocak, M., A. (ed.). Educational digital games. (ss. 2-18). Ankara: Pegem Akademi. 
Çınar, O., Teyfur, E. \& Teyfur, M. (2006). İlköğretim okulu öğretmen ve yöneticilerinin yapılandırmacı eğitim yaklaşımı ve programı hakkındaki görüşleri [Primary school teachers and administrators' views about constructivist education approach and programs]. Education Faculty Journal, 7(11), 47-64.

Doğusoy, B. \& İnal, Y. (2006). Çok kullanıcılı bilgisayar oyunlart ile öğrenme [Learning through multiplayer computer games]. Memo Presented at the VII. National Science and Mathematics Education Congress, Gazi Education Faculty, Ankara.

Domínguez, A., Saenz-de-Navarrete, J., De-Marcos, L., Fernández-Sanz, L., Pagés, ～C. \& Martínez-Herráiz, J. J. (2013). Gamifying learning experiences: Practical implications and outcomes. Computers \& Education, 63, 380-392.

Duatepe, A. \& Çilesiz, Ş. (1999). Matematik Tutum Ölçeğinin Geliştirilmesi [Development of Mathematical Attitude Scale]. Hacettepe University Journal of Education 16-17 : 45-52.

Franke, L., \& Kazemi, E. (2001). Learning to teach mathematics: focus on student thinking. Theory into Practice. Spring, 40(2), 102-109.

Gateway. (2004). One-to-One laptop initiatives: Providing tools for 21st century learners. Folsom, CA: Center for Digital Education.

Gökkaya, Z. (2014). Yetişkin eğitiminde yeni bir yaklaşım: Oyunlaştırma [A new approach of adult educatıon: dramatızatıon abstract]. Hasan Âli Yücel Faculty of Education Journal, 11(1), 71-84.

Güneş, H. (2010). Geliştirilen çevrimiçi elektrogame oyununun ilköğretim 4. basamak bilişim teknolojisi dersi başarisina etkisi [The effect of the developed online electrogame game on the achievement of primary school 4th grade information technology course]. Master thesis. Balikesir University Institute of Science, Balıkesir.

Hanus, M. D. \& Fox, J. (2015). Assessing the effects of gamification in the classroom: A longitudinal study on intrinsic motivation, social comparison, satisfaction, effort, and academic performance. Computers \& Education, 80, 152-161.

Hürriyet Newspaper (2016). MEB'in eğitim programı EBA tanıtıldı [Education program of MONE introduced EBA]. http://www.hurriyet.com.tr/egitim/mebin-egitim-programi-eba-tanitildi-30256965 in 11.11.2016.

İnal, Y. \& Çağıltay, K. (2005). İlköğretim öğrencilerinin bilgisayar oynama alışkanlıklarl ve oyun tercihlerini etkileyen faktörler [Examining Computer Game Habit Level of Primary School Students in Terms of Different Variables]. New Tendencies in Education II. Educational Game Symposium, Ankara Özel Tevfik Fikret Schools, Ankara.

Kablan, Z. (2010). Öğretim sürecinde bilgisayara dayalı alıştırma amaçlı oyun kullanılmasının eğitim fakültesi öğrencilerinin akademik başarısına etkisi [The effect of using exercise-based computer games during the process of learning on academic achievement among education majors]. Journal of Educational Sciences in Theory and Practice. 10(1), 335-364.

Korkusuz, M. E. (2012). Elektrogame eğitsel oyununun tasarlanıp geliştirilerek basit elektrik devresi konusunda bilişsel ve duyuşsal değişkenlere etkisinin incelenmesi [Design and development of the educailonal game named 'electrogame' and analysis of its effect on the cognitive and affective variables regarding the

topic of simple electrical circuits]. Unpublished Doctorate Dissertation. Balıkesir University, Balıkesir.

Kula, A. \& Erdem, M. (2005). Öğretimsel bilgisayar oyunlarının temel aritmetik işlem becerilerinin gelişmesine etkisi [The effect of educa tional computer games on the development of basıc arıthmetıcal operation sk1lls]. Hacettepe University Journal of Education Faculty, 29(29), 127-136.

Malta, S. E. (2010). İlköğretimde kullanılan ĕgitsel bilgisayar oyunlarının öğrencilerin akademik başarısına etkisi [The Effects of Educational Computer Games on Students' Attitudes towards Mathematics Course and Educational Computer Games]. Unpublished Doctorate Dissertation. Sakarya University İnstitute of Social Sciences, Sakarya.

MEB (1996). Türk Ansiklopedisi[Turkish Encyclopaedia]. Ankara: Milli Eğitim Printing House. 
Milliyet Newspaper (2016). EBA kurs hizmetinden yararlanabilmek için başvurular ne zaman yapılacak? [When will applications be made to benefit from the EBA course service?] http://www.milliyet.com.tr/eba-kurs-hizmetinden- gundem- 2307472/ adresinden 11.11.2016 tarihinde alınmıştır.

Obut, S. (2005). İlköğretim 7. Sınıf, maddenin içyapısına yolculuk ünitesindeki atomun yapısı ve peryodik çizelge konusunun eğitsel oyunlarla bilgisayar ortamında öğretimi ve buna yönelik bir model gelistirme[Teaching the subject of The Structure of Atom and Periodic Table in the Unit Exploring the Interior Structure of Substance in Science course at 7th grade in primary education by means of educational games designed on computer and developing a prototype for it]. Unpublished master thesis. Celal Bayar University, Manisa.

Ocak, M. A. (2013). Eğitsel dijital oyunların eğitimde kullanımı [The use of educational digital games in education]. Ocak, M. A. (ed.). Eğitsel dijital oyunlar.(s. 2-18). Ankara: Pegem Akademi

Öncü, H. (2003). Çoktan seçmeli testler [multiple choice tests]. TSA Dergisi,7(2), 87-103.

Özdemir, M. (2010). Nitel veri analizi: Sosyal bilimlerde yöntembilim sorunsalı üzerine bir çalışma [Qualitative data analysis: A study on methodology problem in social sciences]. Eskişehir Osmangazi University Journal of Social Science ,11(1), 323-343.

Polat, Y. (2014). Bir vaka incelemesi: Oyunlaştırma yöntemi ve Ingilizce öğrencilerinin motivasyonları üzerine etkisi[A case study: Gamification and the effect on the motivation of ESL learners]. Unpublished master thesis, Çăg University Institute of Social Science, Mersin.

Samur, Y. (2015, Nisan). Gamifying a hybrid graduate course. Paper presented at the Global Learn Conference, FernUniversitat in Hagen, Berlin, Germany.

Smith, M. (2000). Redefining success in mathematics teaching and learning.Mathematics Teaching in the Middle School, 5(6), 378-389

Sönmez, M. T. \& Dinç, P. (2011, Haziran). Web üzerinden sunulan eğitsel matematik oyunlarının kesirler ve ondalık sayllara ilişkin ögrenci başarısına etkisi [Effect of educational mathematical games presented via the web on student achievement regarding fractions and decimals]. 10th National Science and Mathematics Education Congress, Niğde University, Faculty of Education, Niğde.

Şahin, M. (2015). Oyunlaşmış oyun temelli öğrenmenin öğrencilerin fen bilimleri başarılarına ve derse yönelik tutumlarina etkisi [The effect of gamıfied game based learning on students' achievements and attıtudes towards sclence]. Unpublished Doctorate Dissertation, Bahçeşehir University, İstanbul.

TDK (2014). Oyun kavramının tanımı [Definition of game concept], http://tdk.gov.tr/index.php?option=com_gts adresinden 25 Şubat 2015 tarihinde edinilmiştir.

Yağı, E. (2007). Oyun tabanlı öğrenme ortamlarının ilköğretim ögrencilerinin bilgisayar dersindeki başarıları ve öz-yeterlilik algllarl üzerine etkileri[The effects of game-based learning environments on students' achievement and self-efficacy in a primary school computer course]. Unpublished Doctorate Dissertation, Hacettepe University İnstitute of Science, Ankara.

Yavuz, S. \& Coşkun, A.E. (2008). Sınıf Öğretmenliği Öğrencilerinin Eğitimde Teknoloji Kullanımına Yönelik Tutum ve Düşünceleri [Attıtudes and perceptions of elementary teachıng through the use of technology in education]. H. U. Journal of Education,34, 276-286.

Yenilmez \& Dereli, (2009). İlköğretim Okullarında Matematiğe Karşı Olumsuz Önyargı Oluşturan Etkenler[The Factors Which Form Negatıve Prejudices Agaınst Mathematıcs In Prımary Schools]. e-Journal of New World Sciences Academy, 4(1), 25-33 